\title{
CONTRASTS IN SILLIMANITE DEFORMATION IN FELSIC TECTONITES \\ FROM ANHYDROUS GRANULITE- AND HYDROUS AMPHIBOLITE-FACIES SHEAR ZONES, WESTERN CANADIAN SHIELD
}

By

\section{SHANNON RAE LESLIE}

B.S., San Jose State University, 2007

\author{
A thesis submitted to the Faculty of the Graduate School of the \\ University of Colorado in partial fulfillment of the requirement for the degree \\ Master of Science \\ Department of Geological Sciences
}

2012 
This thesis entitled:

Contrasts in sillimanite deformation in felsic tectonites

from anhydrous granulite- and hydrous amphibolite-facies shear zones, western Canadian Shield

written by Shannon Rae Leslie

has been approved by the Department of Geological Sciences

Kevin Mahan

Rebecca Flowers

G. Lang Farmer

May 9, 2012

The final copy of this thesis has been examined by the signatories, and we find that both the content and the form meet acceptable presentation standards of scholarly work in the above mentioned discipline. 
Leslie, Shannon Rae (M.S., Department of Geological Sciences) Contrasts in sillimanite deformation in felsic tectonites from anhydrous granulite- and hydrous amphibolite-facies shear zones, western Canadian Shield Thesis directed by Assistant Professor Kevin H. Mahan

The deformation behavior of crustal materials in variably hydrated metamorphic environments can drastically alter the rheological and seismic properties of continental crust. The Athabasca granulite terrane in the western Canadian Shield exposes tectonized highpressure granulite that is locally overprinted by crustal-scale amphibolite facies shear zones and thus, provides a natural laboratory for studying deep crustal deformation under variable metamorphic conditions. This study focuses on sillimanite deformation behavior in felsic tectonites from two general deformation settings. First, felsic tectonites with an anhydrous assemblage of Grt + Sil + Kfs + PI + Qtz in the Cora Lake shear zone (CLsz) experienced sinistral shear under estimated conditions of $1.0 \mathrm{GPa}, 800-900^{\circ} \mathrm{C}$. Optical observations and electron backscatter diffraction (EBSD) analyses indicate that dislocation creepaccommodated subgrain-rotation on both (100)[001] and (010)[001] was the dominant dynamic recrystallization mechanism operating in sillimanite under these conditions. Locally, strain was apparently concentrated in surrounding weaker phases (quartz and feldspar) and intracrystalline deformation did not occur in sillimanite. New monazite geochronology suggests that high-strain in the CLsz occurred at c. $1.89 \mathrm{Ga}$. 
The deformation behavior of sillimanite is markedly different under hydrous conditions in the Grease River shear zone (GRsz). The GRsz is characterized by c. 1.80 Ga exhumation involving dextral synkinematic hydration and retrograde metamorphism at $0.4-0.5 \mathrm{GPa}, 550$ $650^{\circ} \mathrm{C}$. Dissolution-reprecipitation is the major dynamic recrystallization mechanism operating in sillimanite under these conditions. Synkinematic growth of foliation-parallel euhedral sillimanite is in a preferred orientation with [001] parallel to the shear direction and either (100) or (010) parallel to the foliation. One important conclusion of this study is that sillimanite [001] preferentially aligns parallel to the stretching lineation regardless of contrasts in the conditions and/or mechanisms of deformation, which has significant implications for crustal anisotropy. 


\section{ACKNOWLEDGEMENTS}

This research was supported by a National Science Foundation grant to Kevin Mahan (EAR-0948581).

I owe many thanks to several people who helped this work come to be. I owe particularly considerable gratitude to my faculty advisor, Kevin Mahan, without whose unfailing patience and guidance I would not have completed this work. Thanks are also due to the faculty and staff of the University Colorado Geological Sciences Department. I would also like to give special thanks to Roy Geiss of the University of Colorado Nanomaterials Characterization Facility for his assistance with EBSD data collection, and to Julien Allaz for his assistance with monazite geochronology data collection at the University of Massachusetts electron microprobe facility.

Throughout this project I received technical assistance from several people and I would like to acknowledge the following: Rachel Landman for exceptional field work assistance and general support in the field, Alexis Ault for her assistance and enthusiasm with almost everything, Dustin Ward for his assistance and guidance with several tasks, John Drexler for assistance on the electron microprobe, Michael Williams for guidance and enlightening conversation, Michael Jercinovic for assistance at the University of Massachusetts electron microprobe facility, Sean Regan for his contagious enthusiasm and assistance with several tasks, Mark Holland for field work assistance, and Paul Boni, Tyler Kane, and Nikolas Mirhashemi for their assistance with sample preparation.

Finally, I would like to thank my family and friends for uninhibited love, encouragement, and support...this work would not have been accomplished without them. 


\section{CONTENTS}

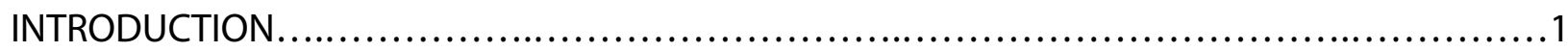

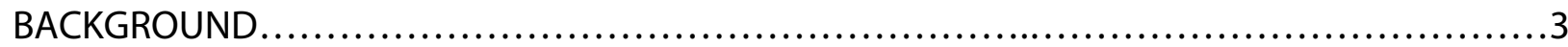

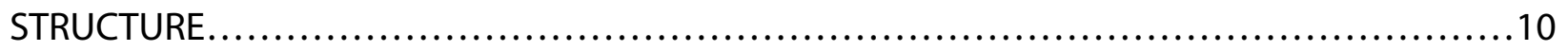

GENERAL MINERALOGY AND TEXTURE............................................ 15

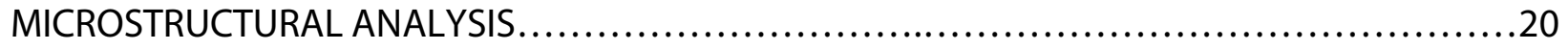

SILLIMANITE MICROSTRUCTURE................................................ 20

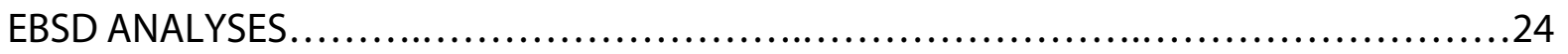

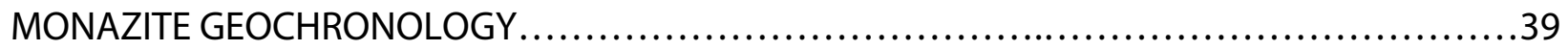

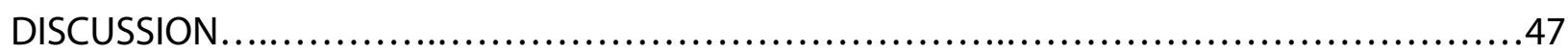

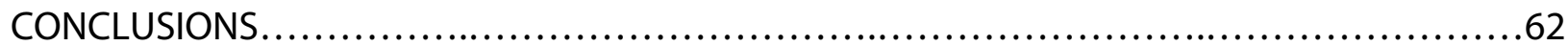

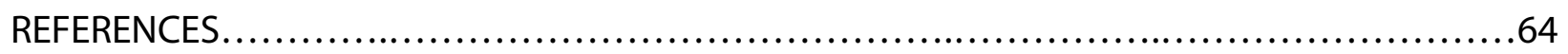




\section{TABLES}

Table

1. Sample summaries............................................................ 12

2. Monazite trace element compositions and calculated dates.......................40 


\section{FIGURES}

Figure

1. Geologic and tectonic maps of the western

Canadian Shield and East Athabasca mylonite triangle...

2. Generalized P-T-t-D paths.....................................................

3. Cora Lake shear zone geological map and structural elements.......................11

4. Photomicrograph and X-ray map of anhydrous

felsic granulite samples showing textural context................................17

5. Photomicrographs showing sillimanite microstructure...........................21

6. [001] EBSD texture map of sillimanite in sample 10W-098A.........................27

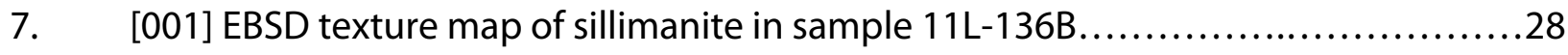

8. Sillimanite pole figures for anhydrous felsic granulite samples......................30

9. [001] EBSD texture map of sillimanite in sample 03M166B............................

10. [001] EBSD texture map of sillimanite in sample 04G-029B......................33

11. Sillimanite pole figures for hydrous felsic amphibolite samples.....................35

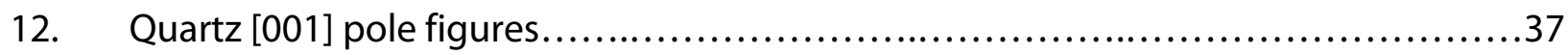

13. Monazite X-ray maps and BSE images..........................................43

14. Summary of monazite geochronology results................................45

15. Summary model for evolution of felsic tectonites..................................57 


\section{INTRODUCTION}

Aqueous fluid content can vary widely in crustal metamorphic environments (e.g., Yardley, 2009). Fluid mobility commonly plays a significant role in mass and heat transport, and fluid infiltration (especially if synkinematic) can drastically alter the rheological properties of rocks and minerals and may induce significant metamorphic transformations and dynamic crustal weakening (e.g., Etheridge et al., 1983; Yardley, 2009; Marsh et al., 2011). Therefore, studies that explore deformation of continental crust under variably hydrated conditions can inform about the processes and factors that influence strain localization and rheological heterogeneities in the crust in general.

The Athabasca granulite terrane (AGT) in the western Canadian Shield comprises a large exposure of tectonized high-pressure granulite that is locally overprinted by retrograde km-

scale amphibolite-facies shear zones (e.g., Mahan \& Williams, 2005). Thus, the AGT provides an ideal opportunity to study the deformation behavior of deep crustal tectonites across a range of temperature, pressure, and hydration conditions. This study focuses on sillimanite deformation in felsic tectonites, which are a common lithology in both granulite- and amphibolite-facies shear zones in the AGT. Sillimanite is the most dominant alumino-silicate polymorph in granulite-facies rocks (e.g., Kerrick, 1990) and is widely observed to develop syntectonically in amphibolite-facies shear zones (e.g., Vernon, 1979; Wintsch \& Andrews, 1988; Musumeci, 2002). Furthermore, sillimanite is thought to be a potentially significant contributor to seismic anisotropy in deep continental crust (Weiss et al., 1999), and thus understanding the mechanisms and factors that are conducive to its crystallographically preferred orientation is important. However, only a few studies have performed quantitative 
analyses on deformation-induced crystallographic fabrics in sillimanite (i.e., Doukhan \& Christie, 1982; Doukhan et al., 1985; Lambregts \& van Roermund, 1990; Goergen et al., 2008) and interpretations of active slip systems are disparate.

The purpose of this study is to characterize the deformation and recrystallization mechanisms operating in sillimanite in felsic tectonites from two broad deformation settings in the Athabasca granulite terrane: the granulite-facies Cora Lake shear zone and the amphibolite-facies Grease River shear zone. Optical observations and electron backscatter diffraction (EBSD) analyses are used to characterize deformation microstructures and mechanisms of sillimanite, and to address the extent to which factors such as temperature, relative fluid-content, and strain localization contributed to these processes. The results highlight dislocation creep-accommodated subgrain-rotation and dissolution-reprecipitation as the major dynamic recrystallization mechanisms in sillimanite from anhydrous granuliteand hydrous amphibolite-facies conditions, respectively. Other scenarios also exist where intracrystalline deformation does not occur at all in sillimanite and rather strain is apparently localized in surrounding weaker phases. Another critical element in investigating deformation histories involves determination of the relative and absolute timing of fabric development. Therefore, new monazite geochronology is also presented that further constrains the timing of the Paleoproterozoic tectonometamorphic evolution of felsic tectonites from lower-crustal to mid-crustal conditions. 


\section{BACKGROUND}

\section{Geological Setting}

The Snowbird Tectonic Zone is the $>2800 \mathrm{~km}$ long northeast trending geophysically defined boundary between the Rae and Hearne domains of the western Churchill Province (Fig. 1a; Hoffman, 1988). High-P granulite terranes are discontinuously exposed along the length of the Snowbird Tectonic Zone. The central portion, well exposed north of the $1.7 \mathrm{Ga}$ Athabasca basin, is the Athabasca granulite terrane (AGT) which consists of $>20,000 \mathrm{~km}^{2}$ of lower continental crust (Fig. 1a; e.g., Hanmer et al., 1994; Mahan \& Williams, 2005). The southernmost portion of the AGT is the East Athabasca mylonite triangle (Tantato domain of Slimmon (1989)), which is separated into three lithotectonic subdomains: southern, northwestern, and Chipman (Fig. 1b; Hanmer, 1994, 1997). All domains consist of 3.2 to $2.6 \mathrm{Ga}$ igneous protoliths (Fig. 1c) that have been reworked by at least two high-pressure granulite facies tectonometamorphic events: one at c. 2.6-2.5 Ga and the other at c. 1.9 Ga (Hanmer et al., 1994, 1995a; Snoeyenbos et al., 1995; Williams et al., 1995, 2000; Kopf, 1999; Baldwin et al., 2003, 2004, 2006; Flowers et al., 2006a; Mahan et al., 2006b; Dumond et al., 2008). The southern domain structurally overlies the northwestern domain along a dip-slip shear zone and consists of c. 2.6 Ga mafic and felsic granulite and local lenses of eclogite (Hanmer, 1994; Hanmer et al., 1995b) that record conditions of $\geq 1.5 \mathrm{GPa}, 750-1000^{\circ} \mathrm{C}$ (Snoeyenbos et al., 1995; Baldwin et al., 2003, 2004, 2007). The northwestern domain is dominated by c. $2.6 \mathrm{Ga}$ felsic to mafic metaplutonic gneisses and interlayered felsic granulite (Hanmer, 1994, 1997; Hanmer et al., 1994). The metaplutonic rocks record metamorphic conditions of $\sim 1.0 \mathrm{GPa}$, $700-800^{\circ} \mathrm{C}$ (Williams et al., 2000) and melt-enhanced ESE-directed subhorizontal shear fabrics 

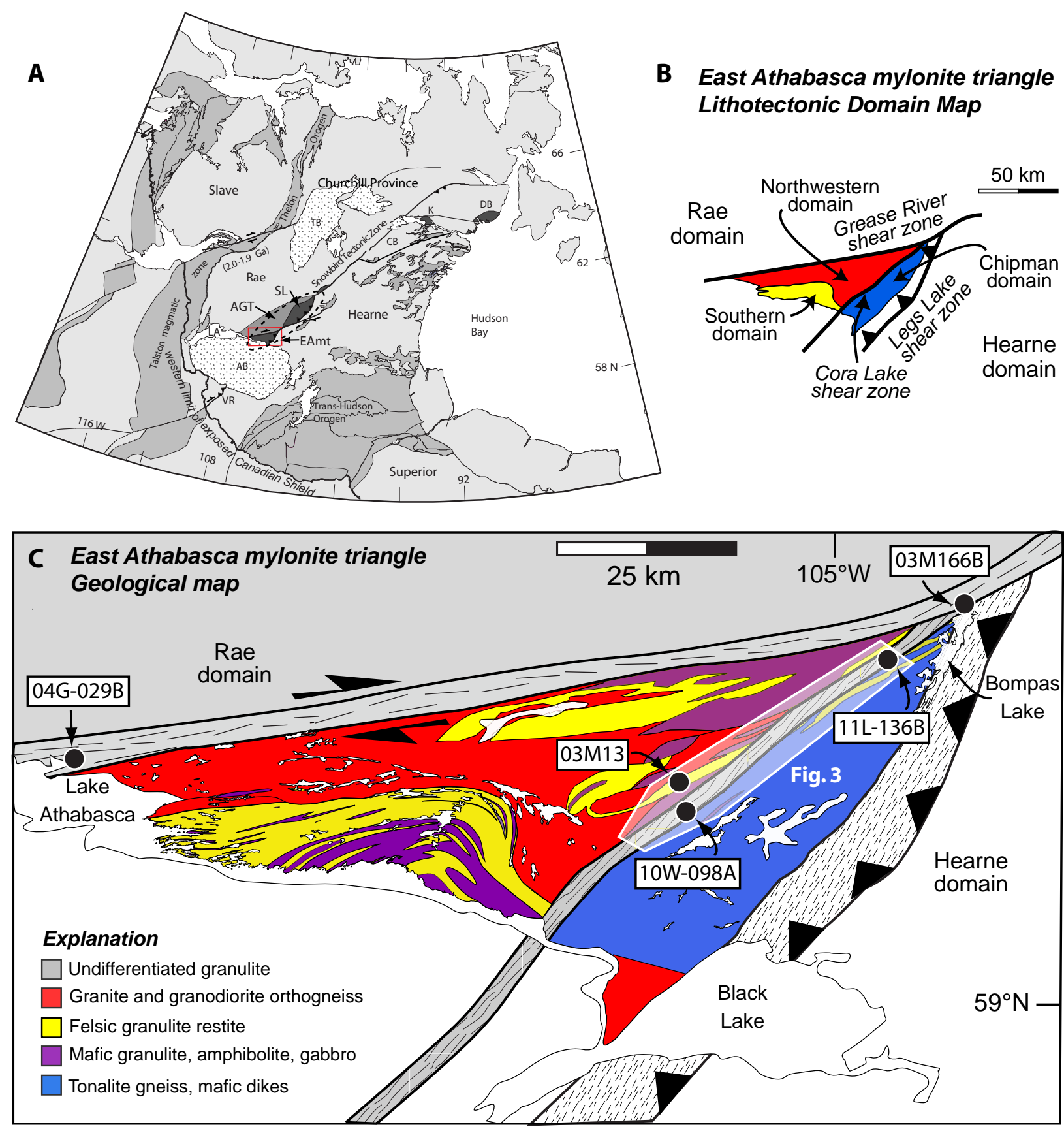

Fig. 1. (A) Simplified geologic and tectonic map of the western Canadian Shield. EAmtEast Athabasca mylonite triangle (outlined in red); SL-Snowbird Lake area; AGTAthabasca granulite terrane (outlined in dashed black; includes EAmt and SL); ABAthabasca basin; CB-Chesterfield block; DB-Daly Bay complex; K-Kramanituar complex; TB-Thelon basin; VR - Virgin River shear zone. (B) Key to major lithotectonic subdomains and shear zones of the East Athabasca mylonite triangle. (C) Geological map of the East Athabasca mylonite triangle. The locations of all five samples shown. Area of Fig. 3 outlined in white and shaded. After Mahan et al. (2011) and compiled from Hanmer (1994) and Mahan \& Williams (2005). 
(Dumond et al., 2010). The Chipman domain largely consists of c. 3.2 Ga heterogeneous tonalite gneiss, which hosts the Chipman mafic dike swarm and minor interlayered mafic, intermediate, and felsic granulite (Hanmer, 1994; Mahan et al., 2008; this study). Highpressure granulite facies metamorphism and coupled deformation in the Chipman domain at c. $2.55 \mathrm{Ga}$ and c. $1.9 \mathrm{Ga}$ are recorded in polymetamorphic mafic granulites and further constrained by the anatexis of mafic dikes (discussed further below). The northwestern and Chipman domains are separated by the NE striking, steeply NW dipping Cora Lake shear zone (Mahan et al., 2008).

The Legs Lake and Grease River shear zones are exhumation-related structures that bound the East Athabasca mylonite triangle (Fig. 1b, c; e.g., Mahan \& Williams, 2005). The Legs Lake shear zone marks the structural and metamorphic boundary between high-P granulite facies rocks of the Rae domain and supracrustal amphibolite facies rocks of the Hearne domain (Mahan et al., 2003; Mahan \& Williams, 2005). The Legs Lake shear zone records east-vergent thrusting and at least $20 \mathrm{~km}$ of vertical offset during the interval of 1850-1800 Ma (Mahan \& Williams, 2005; Mahan et al., 2006a). The Grease River shear zone is a $400 \mathrm{~km}$ long zone of amphibolite to greenschist facies and ductile-brittle tectonite that overprinted and offset the Legs Lake shear zone by 110 km c. 1800 Ma (Mahan \& Williams, 2005; Mahan et al., 2006b).

\section{Previous work: Thermobarometry and Geochronology}

The felsic tectonites sampled for this study are from two broad structural locations: the Cora Lake shear zone and the Grease River shear zone. First, the conditions and timing of Late Archean tectonometamorphism are briefly reviewed. However, because this study 
predominantly pertains to Paleoproterozoic tectonometamorphism, previous work on the conditions and timing of those events is reviewed in more detail.

\section{Late Archean tectonometamorphism}

All samples from this study are interpreted to be derived from the same felsic protolith $(\mathrm{Grt}+\mathrm{Sil} / \mathrm{Ky} \pm \mathrm{Crn} \pm \mathrm{Rt}+\mathrm{Kfs}+\mathrm{Pl}+\mathrm{Qtz})$ that formed during Late Archean peak metamorphism. This is supported by the similar REE patterns observed in felsic granulite from the western Chipman domain and that in the southern domain (Flowers et al., 2008).

A brief review of constraints on conditions and timing of Late Archean tectonometamorphism in the Chipman and northwestern domains is important for understanding the origin of the felsic protolith for samples in this study. Mafic rocks of the western Chipman domain record metamorphism at $1.3 \mathrm{GPa}, 850-900{ }^{\circ} \mathrm{C}$ coupled with shallow gneissic fabric $\left(S_{1 c}\right)$ development (Fig. 2; Mahan et al., 2008) at 2554.5 $\pm 4.3 \mathrm{Ma}$ (Flowers et al., 2008). In the northwestern domain, syntectonic emplacement of the granitoid into the intermediate-pressure granulite field, $\sim 0.9-1.1 \mathrm{GPa}, 900^{\circ} \mathrm{C}$ (Fig. 2; Williams et al., 2000), occurred at c. 2.63-2.60 Ga (Baldwin et al., 2003). The granitoid then cooled isobarically to $\sim 750^{\circ} \mathrm{C}$ (Williams et al., 2000), where deformation and metamorphism continued and a subhorizontal gneissic fabric $\left(\mathrm{S}_{1 \mathrm{~N}}\right)$ developed at c. 2.60 - $2.55 \mathrm{Ga}$ (Fig. 2; Dumond et al., 2010).

\section{Anhydrous felsic tectonite (Cora Lake shear zone)}

Following a period of $>600$ million years of deep crustal residence and isobaric cooling (Fig. 2), a return to high-temperature conditions occurred at $\sim 1.9 \mathrm{Ga}$ (Mahan et al., 2008). In the Chipman domain, this event is characterized by a progression from $\sim 1.0 \mathrm{GPa}, 700-750{ }^{\circ} \mathrm{C}$ in its early stages to a period of amphibole dehydration and granulite facies metamorphism at 


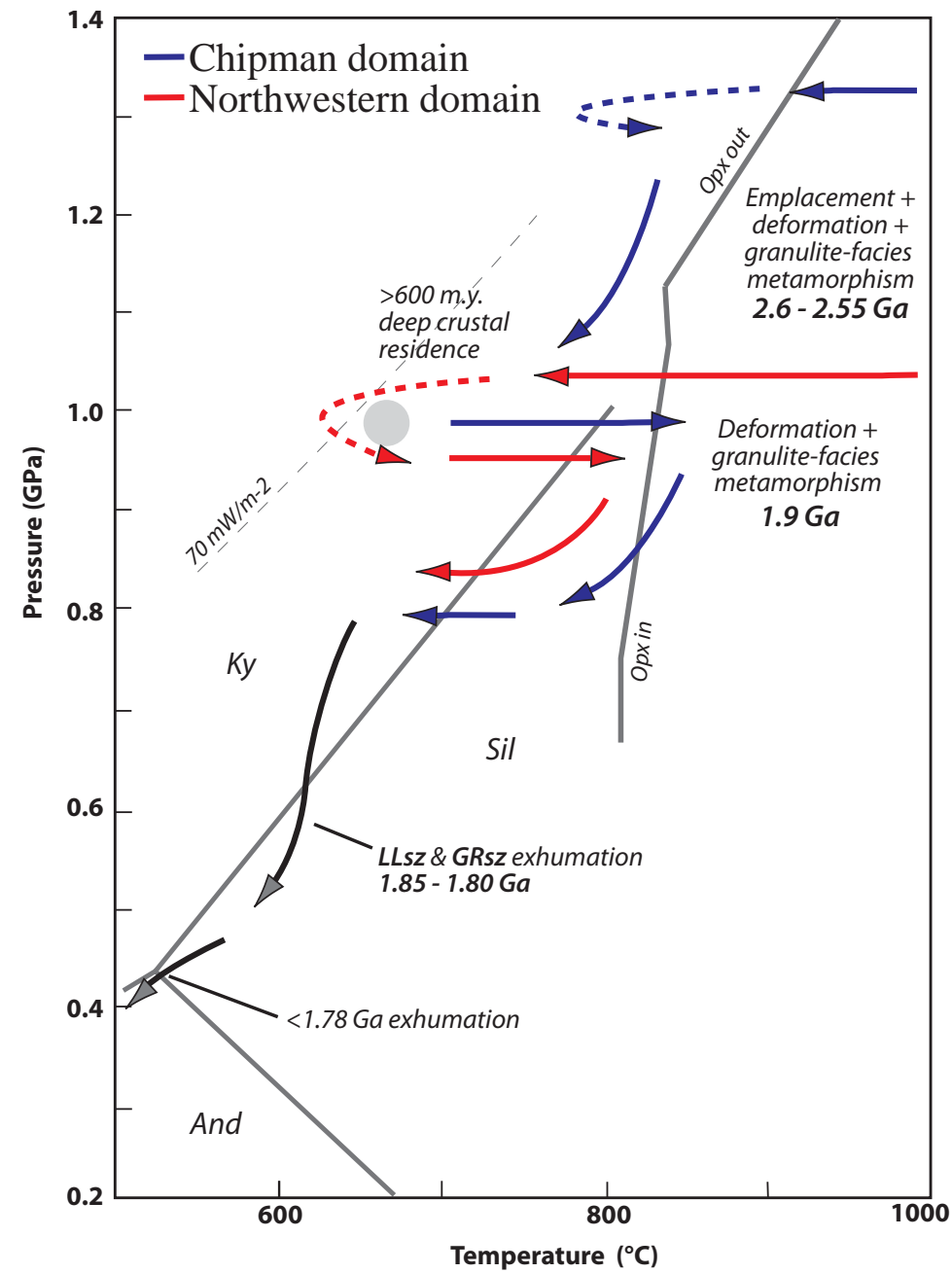

Fig. 2. Generalized composite P-T-t-D paths for the Chipman (blue) and northwestern (red) domains in the East Athabasca mylonite triangle. Modified after Mahan et al. (2011). 
1.0 GPa, 800-900 ${ }^{\circ} \mathrm{C}$ (Fig. 2; Mahan et al., 2008). Zircon in mafic granulite from the Cora Lake region yielded a lower intercept U-Pb ID-TIMS date of $1896 \pm 18 \mathrm{Ma}$ (Flowers et al., 2008). This event involved steep fabric $\left(\mathrm{S}_{2}\right)$ development and is likely to coincide with emplacement and metamorphism of the Chipman mafic dike swarm (Mahan et al., 2008; Flowers et al., 2008). Partial melting of mafic dikes in the eastern Chipman domain occurred at 1.0-1.2 GPa, 750-850 ${ }^{\circ} \mathrm{C}$ (Williams et al., 1995) and is dated by zircon from the leucosome at $1896 \pm 0.3 \mathrm{Ma}$ (Flowers et al., 2006a).

The relationship between metamorphism and steep fabric $\left(\mathrm{S}_{2 \mathrm{~N}}\right)$ development in northwestern domain at $1.9 \mathrm{Ga}$ is somewhat elusive; preliminary results have indicated that a steep, dextral fabric in the northwestern domain formed at c. 1.9 Ga and 0.9 GPa (Fig. 2; Regan et al., 2012). This is consistent with steep fabric $\left(S_{2 N}\right)$ development and dextral-reverse oblique strain under high pressures and temperatures $\left(\sim 1.0 \mathrm{GPa}, 650-700^{\circ} \mathrm{C}\right)$ at c. $1.92-1.90$ Ga documented farther west along the Grease River shear zone (Fig. 2; Dumond et al., 2008).

\section{Hydrous felsic tectonite (Grease River shear zone)}

Immediately following the c. 1.9 Ga granulite facies event, a stage of anhydrous decompression is correlated with exhumation of the hanging wall along the Legs Lake shear zone (Fig. 2; Mahan et al., 2006b). Weighted mean Th-U-total Pb dates of $1851 \pm 9 \mathrm{Ma}$ and $1853 \pm 15$ Ma from monazite in two retrograde felsic granulite samples represent the onset of major retrograde metamorphism (Mahan et al., 2006b). Retrogression is characterized by hydration beginning at $0.8-0.7 \mathrm{GPa}$, causing the breakdown of garnet and K-feldspar and the production of biotite and sillimanite (Mahan et al., 2006b). Continued decompression along the Legs Lake shear zone under hydrated conditions led to cordierite production and 
equilibration at $0.5-0.4 \mathrm{GPa}, 550-650^{\circ} \mathrm{C}$ (Mahan et al., 2006b). Where similar retrograde granulites occur in the Grease River shear zone, fracturing and disaggregation of the latestage mineral assemblage parallel to the extension direction is consistent with synkinematic lower amphibolite- to greenschist-facies metamorphism along this structure at c. $1.80 \mathrm{Ga}$ (Hanmer, 1997; Williams \& Jercinovic, 2002; Mahan et al., 2006b). 


\section{STRUCTURE}

Five samples of felsic tectonite were collected from two broad structural areas: the Cora Lake shear zone (Fig. 1, 3) and the Grease River shear zone (Fig. 1). Table 1 provides a summary of sample locations (lake and shear zone), kinematics, metamorphic grade, mineral assemblage, and sillimanite microstructure. As indicated in Table 1, samples from the Cora Lake shear zone region (10W-098A, 03M13,11L-136B) are remarkably different, both in texture and in mineralogy, from samples from the Grease River shear zone (03M166B, 04G-029B). Here, Paleoproterozoic structural elements from the two shear zones (i.e., $\mathrm{S}_{2 \mathrm{C}}$ and $\mathrm{S}_{2 \mathrm{~N}}$ ) are reviewed.

The Cora Lake shear zone (CLsz) is a km-scale mylonite zone that marks the boundary between the Chipman and northwestern domains (Fig. 1b, c; Fig. 3). The fabric in the western Chipman domain is defined by a steeply NW-dipping foliation $\left(S_{2}\right.$; average $\left.=226 / 62\right)$ with a shallow SW-plunging stretching lineation $(\sim 21 \rightarrow 245)$ that intensifies in an ultramylonite zone several tens of meters wide just west of Cora Lake (Fig. 3; Mahan et al., 2008). Kinematic indicators along the CLsz consistently record sinistral strike-slip displacement with a minor extensional component (NW side down). Detailed mapping in the western Chipman domain reveals highly tectonized and intimate ( $\mathrm{m}$-scale) interlayering of mafic, felsic, and intermediate granulite and tonalite gneiss (shown in brown stippled pattern in Fig. 3) that increases northwestward with proximity to the CLsz ultramylonite (Fig. 3). Felsic granulite sample 10W-098A was collected in this high-strain region (Fig. 3). Felsic granulite sample 11L136B was collected in a 100-m-wide ultramylonite zone that is interpreted to be the northern extension of the CLsz (Fig. 3). Although the fabric orientation is quite different $(S=$ 

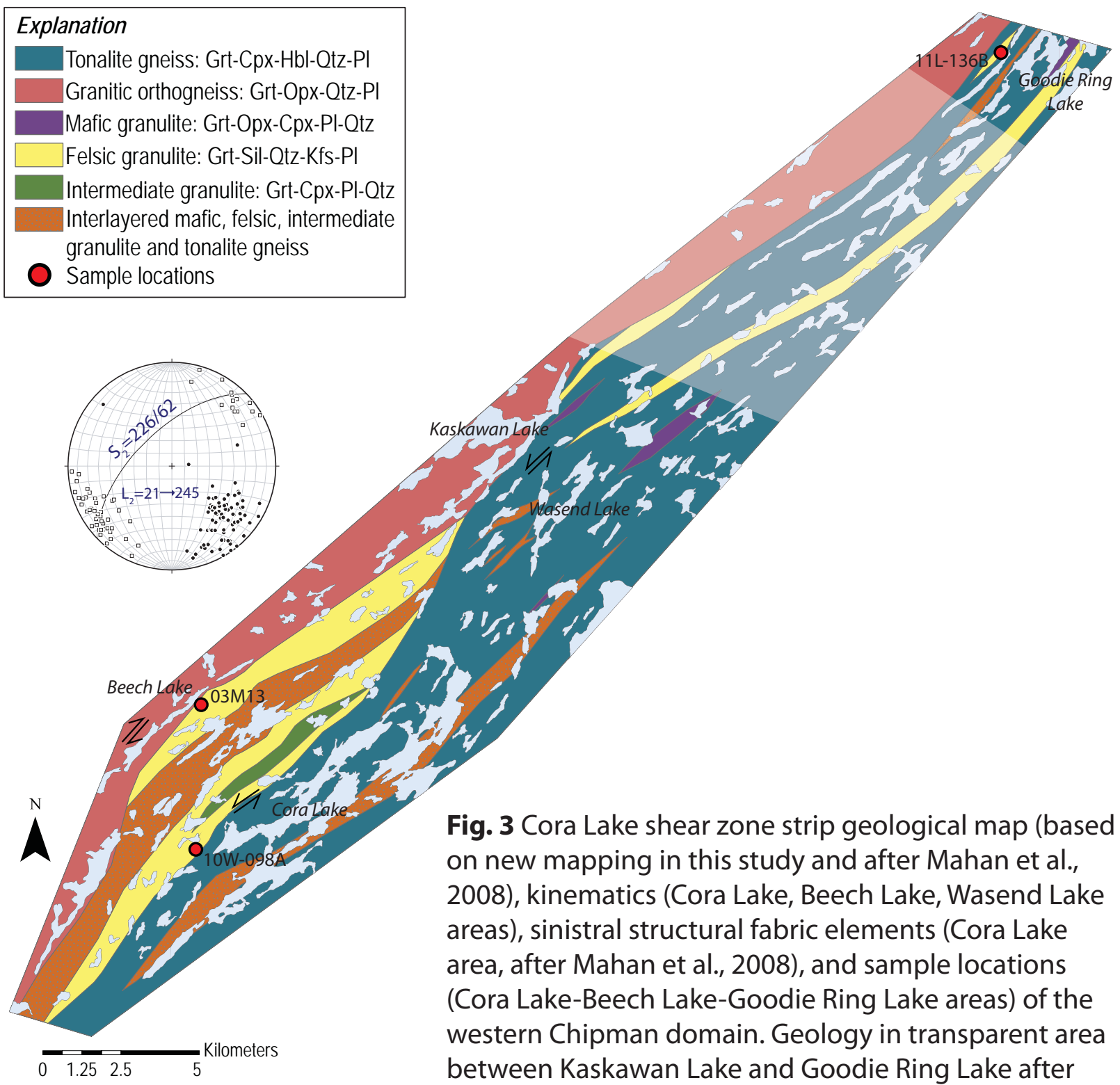

Fig. 3 Cora Lake shear zone strip geological map (based on new mapping in this study and after Mahan et al., 2008), kinematics (Cora Lake, Beech Lake, Wasend Lake areas), sinistral structural fabric elements (Cora Lake area, after Mahan et al., 2008), and sample locations (Cora Lake-Beech Lake-Goodie Ring Lake areas) of the western Chipman domain. Geology in transparent area between Kaskawan Lake and Goodie Ring Lake after Hanmer, 1994. Stereonet notation: solid circles = poles to $S_{2 c}$ foliation; open squares $=L_{2 c}$ stretching lineation. 
Table 1. Sample summaries.

\begin{tabular}{lllllll}
\hline & & Shear & & Metamorphic & & Sillimanite \\
Sample & Location & zone & Kinematics & grade & Mineral assemblage & microstructure* $^{*}$ \\
\hline 10W-098A & Cora Lake & CLsz & sinistral & granulite & Grt-Sil-Kfs-PI-Qtz & Type-1,-2 \\
03M13 & Beech Lake & CLsz? & dextral? & granulite & Grt-Sil-PI-Kfs-Qtz & Type-1,-2 \\
11L-136B & Goodie Ring Lake & CLsz & sinistral? & granulite & Grt-Sil-PI-Kfs-Qtz & Type-1 \\
03M166B & N. Bompas Lake & GRsz & dextral & amphibolite & Grt-Sil-Bt-Crd-PI-Qtz & Type-1,-2,-3 \\
04G-029B & Grease Bay & GRsz & dextral & amphibolite & Grt-Sil-Bt-Msc-PI-Qtz & Type-2,-3 \\
\hline
\end{tabular}

* For sillimanite types: refer to section "Microstructural analysis: Sillimanite microstructure" 
$233 / 44, L=27 \rightarrow 270$, average) and kinematics are indiscernible, this high-strain region approximately corresponds with the boundary between the Chipman and northwestern domains (Fig. 3).

The foliation orientation is consistent between Beech Lake and Cora Lake, however, the fabric intensity weakens northwestward from the CLsz ultramylonite to protomylonite just southeast of Beech Lake. Moreover, other than a few rare sinistral kinematic indicators, shear sense is elusive in this region. Such observations are consistent with a strain gradient from sinistral high-strain ultramylonite at Cora Lake to low-strain protomylonite just southeast of Beech Lake. Felsic granulite sample 03M13 was collected from a low-strain area with indefinite kinematics just southeast of Beech Lake, although it is important to note that unequivocal dextral shear is observed less than $300 \mathrm{~m}$ to the northwest (Fig. 3). Just northwest of Beech Lake (Fig. 3), dextral kinematic indicators are ubiquitous and dextral shear on a steep NW-dipping foliation $\left(\mathrm{S}_{2 \mathrm{~N}}\right)$ generally characterizes the northwestern domain.

The Grease River shear zone (GRsz; Fig. 1b, c) is a several-km wide zone of amphibolite- to greenschist-facies tectonite with a steep $\left(\sim 80^{\circ}\right)$ NW-dipping mylonitic foliation and shallow $\left(27^{\circ}\right)$ SW-plunging stretching lineation (Mahan \& Williams, 2005; Dumond et al., 2008). Dextral strike-slip displacement with a minor component of compression (NW side up) is consistently recorded along the shear zone. Additional characteristics of the GRsz are summarized by Mahan \& Williams (2005). Sample 03M166B was collected at the northern end of Bompas Lake in an area that experienced Legs Lake shear zone deformation and was subsequently overprinted by the GRsz (Fig. 1C). Sample 04G-029B was collected at the southern exposure of the GRsz at Lake Athabasca (Fig. 1c). Both 03M166B and 04G-029B are amphibolite facies 
felsic tectonites that experienced hydration and retrograde metamorphism (and are hereto referred to as "hydrous felsic amphibolites"). 


\section{GENERAL MINERALOGY AND TEXTURE}

Here, the assemblages and textures most closely associated with Paleoproterozoic mylonitization $\left(\mathrm{S}_{2}\right)$ are examined: anhydrous mylonitization in three felsic granulite samples (10W-098A, 03M13, 11L-136B) and hydrous retrograde mylonitization in two felsic amphibolite samples (03M166B, 04G-029B). Mineral assemblages for all five samples are summarized in Table 1. Mineralogical and textural evidence for equilibration under extremely high pressure and temperature conditions, likely representative of Archean peak metamorphism, are also briefly investigated.

\section{Anhydrous felsic granulite 10W-098A, 11L-136B, and 03M13}

Samples of anhydrous felsic granulite 10W-098A, 11L-136B, and 03M13 contain the equilibrium assemblage Grt $+\mathrm{Sil}+\mathrm{Kfs}+\mathrm{PI}+\mathrm{Qtz} \pm \mathrm{Rt}$ with accessory monazite, zircon, and apatite. In samples 10W-098A and 11L-136B, a mylonitic foliation is defined by quartz, Kfeldspar, and plagioclase ribbons that commonly extend the length of the thin section and recrystallized grain-sizes of the same phases ranging from $<10 \mu \mathrm{m}$ to $50 \mu \mathrm{m}$. Equant garnet porphyroblasts range in size from $\sim 0.5 \mathrm{~mm}$ to $\sim 3 \mathrm{~mm}$ in diameter and more elongate garnet clasts with a shape-preferred orientation parallel to the stretching lineation are up to $5 \mathrm{~mm}$ long. Anhedral quartz inclusions are common in garnet. Garnet deformation is restricted to brittle fracturing with pervasive, closely spaced, and subparallel fractures oriented at a high angle to the matrix foliation. In sample $11 \mathrm{~L}-136 \mathrm{~B}$, there are also layers that are almost entirely composed of fractured garnet.

Anhydrous felsic granulite samples 10W-098A and 11L-136B preserve evidence of relict early textures and very high temperature and pressure conditions. In sample 10W-098A, 
polyphase porphyroclasts are preserved that comprise mosaic quartz and feldspar that are generally much coarser-grained $(\sim 100-300 \mu \mathrm{m})$ than ribbon matrix quartz and feldspar (Fig. 5b). Ternary feldspar, which generally equilibrates at $>1000^{\circ} \mathrm{C}$ (e.g., Fuhrman \& Lindsley, 1988), is exsolved into Ca- and Na-plagioclase intergrowths in matrix K-feldspar in sample 10W-098A. Corundum is also locally present as inclusions and partial inclusions in sillimanite porphyroclasts in sample 10W-098A, but not directly in contact with quartz. However, given the high bulk silica content of the rock and that quartz is a ubiquitous inclusion in garnet, it is likely that quartz was in equilibrium with corundum under early peak conditions. The assemblage corundum + quartz suggests equilibration at $>1100^{\circ} \mathrm{C}$ (Anovitz et al., 1993) or metastability under lower temperature conditions (Harlov \& Milke, 2002). In sample 11L-136B, two roughly perpendicular orientations of rutile needles $(\leq 20 \mu \mathrm{m})$ are included in equant garnet porphyroblasts, indicating that $\mathrm{TiO}_{2}$ was incorporated into the garnet crystal structure during growth and was later exsolved to rutile; this texture is positively correlated with pressure and suggests ultra-high pressure crustal conditions in the coesite stability field (Zhang et al., 2003). Similar textures from felsic granulite in the southern domain have been interpreted as developing during metamorphism and partial melting of an igneous protolith at $\geq 1000^{\circ} \mathrm{C}, 0.8-1.0 \mathrm{GPa}$ (Baldwin et al., 2006).

The texture in sample $03 \mathrm{M} 13$ is distinctly different from that of the other two anhydrous felsic granulite samples described above. A gneissic foliation $\left(S_{2}\right)$ in sample 03M13 is defined by compositional layering and grain size variation. Quartzofeldspathic layers range in composition from plagioclase-rich to K-feldspar-rich and alternate with garnet-sillimanitebearing layers (Fig. 4b). Quartzofeldspathic layers also show a range in texture including 

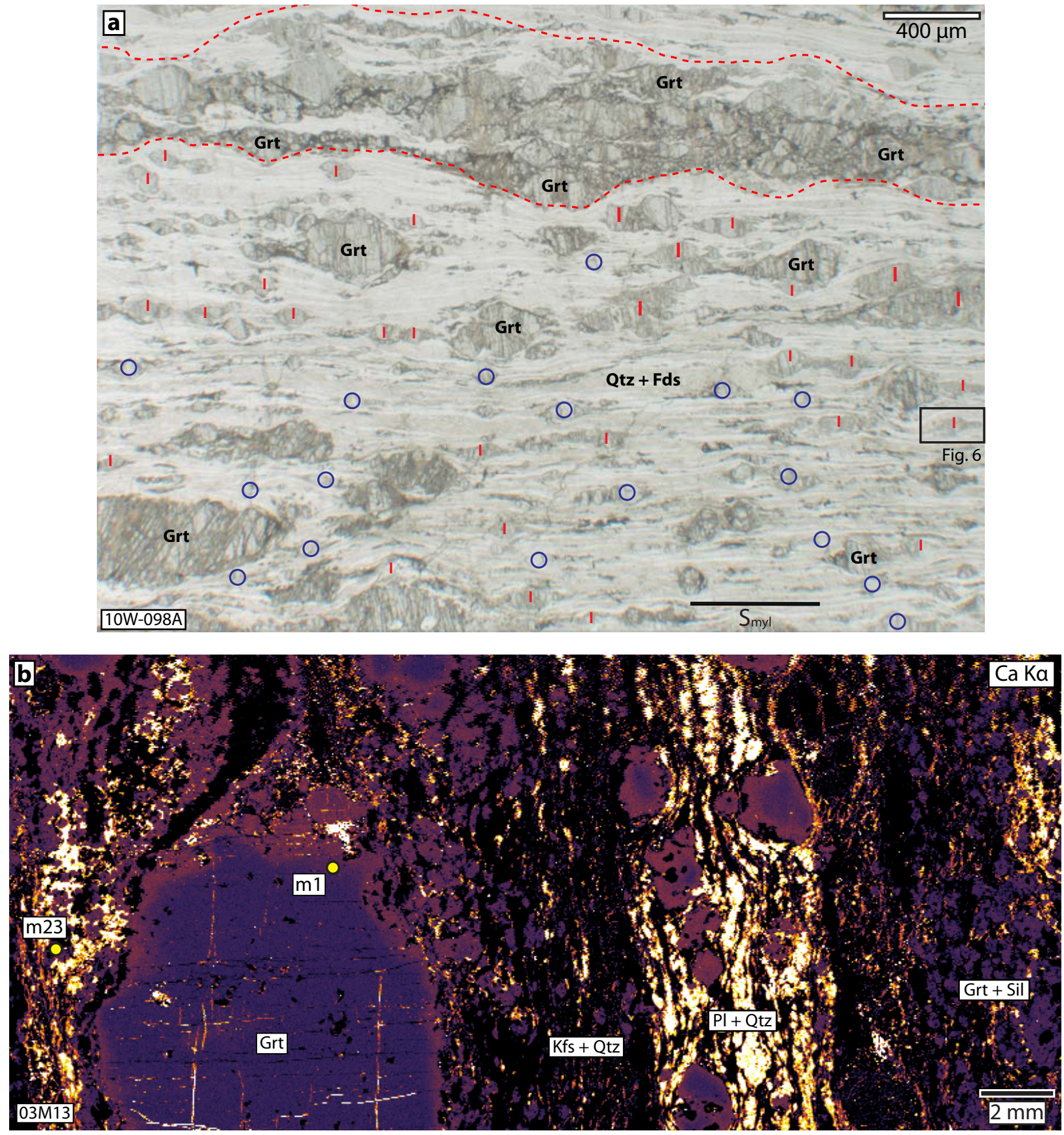

Fig. 4. (a) Photomicrograph of anhydrous felsic granulite 10W-098A showing distribution of type-1 and type-2 sillimanite porphyroclasts. Red dashes and area between dashed red lines denote distribution of type-1 sillimanite. Open blue circles denote type-2 sillimanite. Area of Fig. 6 shown. (b) Ca Ka X-ray map of anhydrous felsic granulite 03M13 showing overall texture. Note the marked increase in $\mathrm{Ca}$ at garnet margins and alternating compositional layers parallel to the gneissic foliation (vertical). Yellow circles denote selected monazite grains shown in Fig. 13. 
discontinuous ribbon mylonite, recrystallized mosaic protomylonite $(\leq 150 \mu \mathrm{m})$, and coarsegrained ( $\geq 200 \mu \mathrm{m})$ granoblastic texture preserved in strain shadows of large porphyroclasts. Rutile $(\leq 200 \mu \mathrm{m})$ occurs as a minor phase in the garnet-sillimanite-bearing layers and locally in the quartzofeldspathic layers where crystals display a shape-preferred orientation parallel to the stretching lineation. Large porphyroclasts of garnet and K-feldspar range in size from $\sim 1.5 \mathrm{~mm}$ to $>8 \mathrm{~mm}$ in diameter. Inclusions of anhedral K-feldspar and quartz grains and elongate sillimanite prisms are ubiquitous in garnet. Notably, garnet porphyroclasts also show a sharp and marked increase in grossular content near the margins (Fig. 4b). Similar Cazonation in garnet is also observed in felsic granulite in the southern domain (Snoeyenbos et al., 1995; Baldwin et al., 2007) and the Chipman domain (Mahan et al., 2006b) and suggests later garnet growth, perhaps at $1.9 \mathrm{Ga}$ (Mahan et al., 2006b; Baldwin et al., 2007), under relatively lower temperature or higher pressure conditions. Finer-grained garnet $(\leq 1 \mathrm{~mm}$ in diameter) also occurs in matrix domains with sillimanite.

\section{Hydrous felsic amphibolite 03M166B and 04G-029B}

Both hydrous felsic amphibolite samples, 03M166B and 04G-029B, show relicts of an anhydrous assemblage that has subsequently been replaced by the retrograde assemblage $\mathrm{Grt}+\mathrm{Sil}+\mathrm{Bt} \pm \mathrm{Crd} \pm \mathrm{Msc}+\mathrm{Pl}+\mathrm{Qtz}$. An anastomosing matrix foliation is characterized by recrystallized granoblastic quartz and plagioclase $(\sim 50-200 \mu \mathrm{m})$, mattes of aligned mica, thin layers of aligned sillimanite prisms, and localized quartzofeldspathic ribbon fabrics. Dextral kinematic indicators include asymmetric garnet and sillimanite sigma clasts and an S-C mylonitic fabric defined by mostly biotite. Sillimanite and garnet porphyroclasts (several $\mathrm{mm}$ ) are pervasively fractured. Importantly, fractures in garnet are filled with biotite \pm cordierite, 
indicating a chemical breakdown of garnet during retrogression. Elongate aggregates of garnet \pm cordierite and development of mica parallel to the foliation suggest that an episode of deformation occurred after garnet breakdown (Mahan et al., 2006b). 


\section{MICROSTRUCTURAL ANALYSIS}

\section{Sillimanite microstructure}

Sillimanite is ubiquitous in all samples; however, its microstructural characteristics are different among the five samples studied. Three distinct types of sillimanite are delineated based on microstructure, morphology, crystallographic fabric, spatial occurrence in the sample (i.e., with garnet or in matrix layers), and sample occurrence. Table 1 provides a list of

the types of sillimanite present in each sample. The main distinction between type- 1 and the other two types of sillimanite is the presence of intracrystalline deformation, notably subgrain microstructure. Type-1 sillimanite is also generally coarser-grained and occurs in rheologically strong (i.e., garnet + sillimanite-bearing) layers (Fig. 4a). Conversely, type-2 sillimanite is generally finer-grained and occurs in relatively weak quartzofeldspathic matrix layers (Fig. 4a). All samples, other than 11L-136B, contain type-2 sillimanite. Type-3 sillimanite exclusively occurs in hydrous felsic amphibolite, is characterized by a high aspect ratio with its long-axis parallel to the stretching lineation, and occurs immediately adjacent to type-2 sillimanite porphyroclasts.

Subgrain microstructure develops during deformation when dislocations accumulate into planar networks, termed subgrain boundaries, separating subgrains that are slightly misoriented relative to one another (Passchier \& Trouw, 1996). Optically, subgrains within a larger parent crystal are separated from other subgrains by discrete, sharp, low relief boundaries; the slight misorientation of subgrains relative to one another creates slight changes in the optical angle of extinction between subgrains. Type- 1 sillimanite in samples 10W-098A and 11L-136B display extensive subgrain microstructure (Fig. 5b). 
Anhydrous felsic granulite

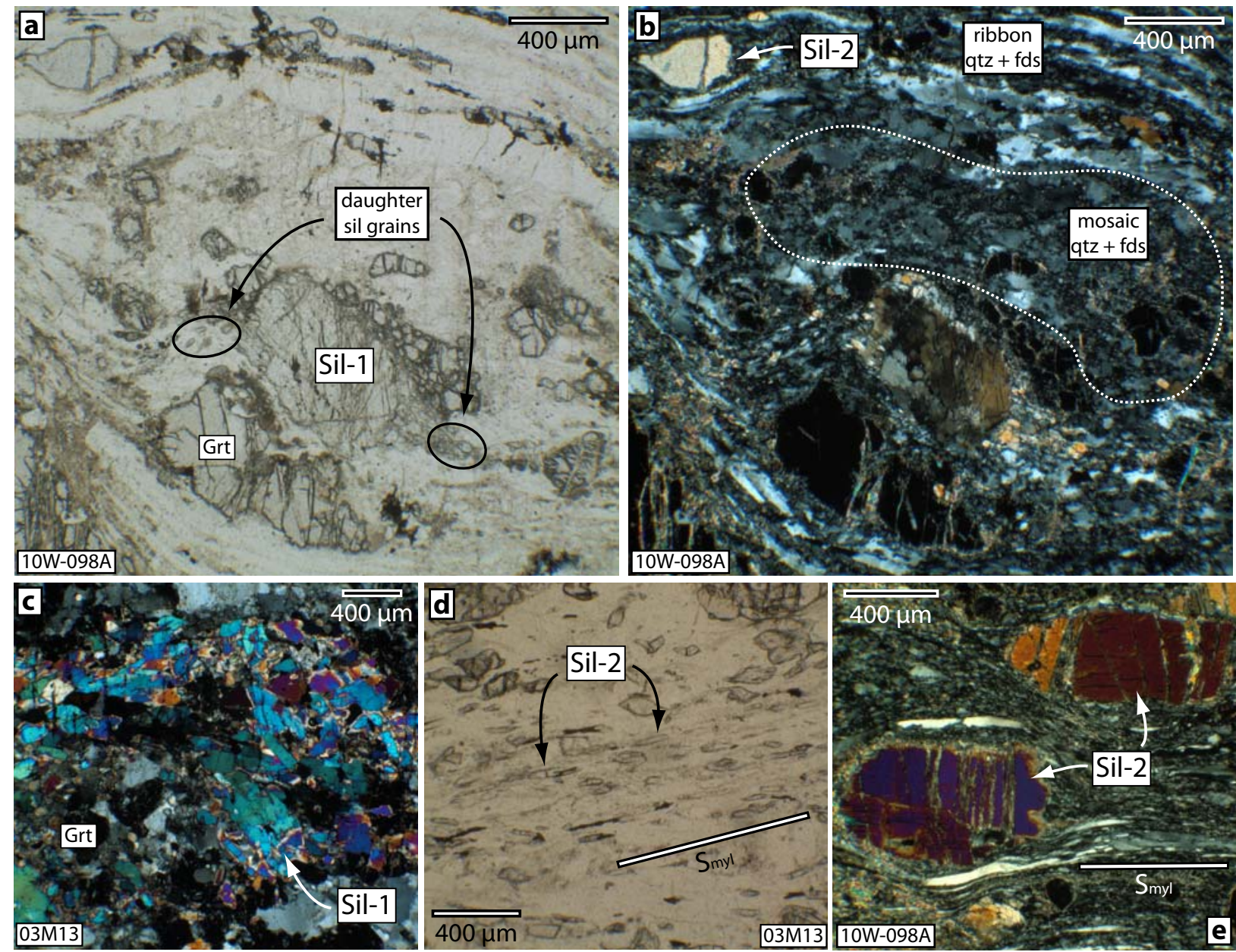

Hydrous felsic amphibolite
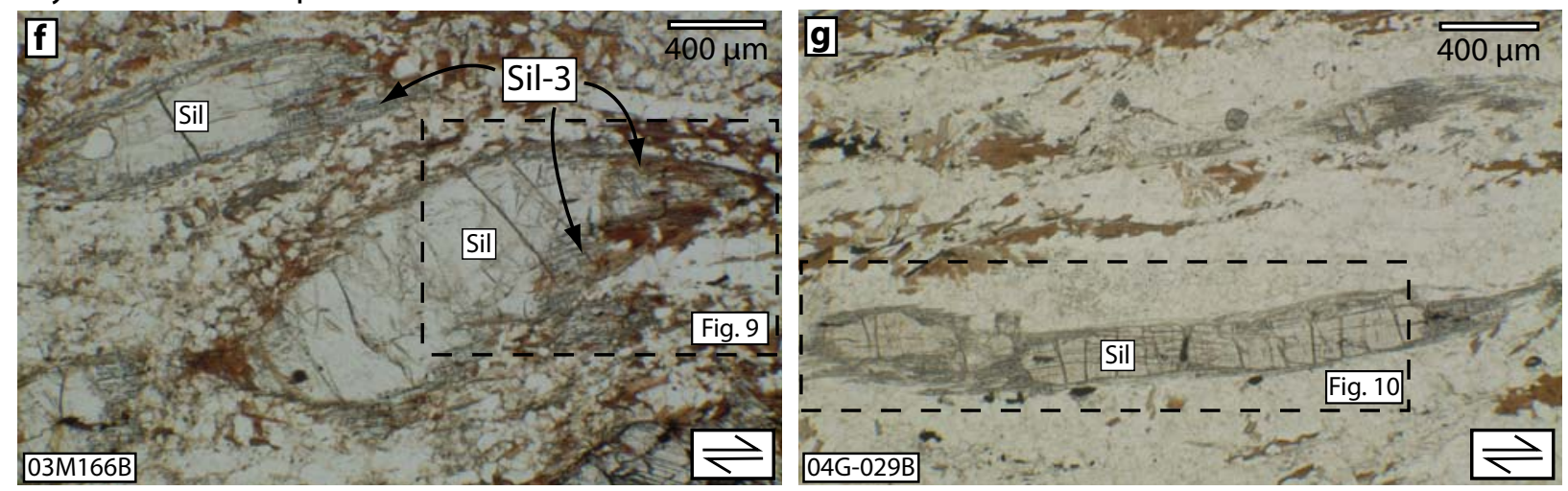

Fig. 5. Photomicrographs of anhydrous felsic granulite (a-e) and hydrous felsic amphibolite (f-g). Sil-1, Sil-2, and Sil-3 refer to type-1, -2, and -3 sillimanite, respectively. Mylonitic fabric and kinematics indicated where appropriate. (a-b) 10W-098A. Polyphase porphyroclast approximately outlined in dashed white line. Type-1 sillimanite and recrystallized daughter grains. (c-d) Type-1 and -2 sillimanite in 03M13. (e) Type-2 sillimanite in 10W-098A. (f-g) Sillimanite in 03M166B and 04G-029B with foliation-parallel sillimanite needles (03M166B type-3). Area of Figs. 9 \& 10 shown in dashed box in (f) \& (g), respectively. 
In sample 11L-136B, type-1 sillimanite porphyroclasts range in size between $\sim 100 \mu \mathrm{m}$ and up to several $\mathrm{mm}$ and subgrain microstructure is pervasive. Type-1 sillimanite porphyroclasts in sample 10W-098A are $\leq 3 \mathrm{~mm}$ prisms with a lineation-parallel shape preferred orientation and display extensive internal subgrain microstructure (Fig. 5a, b). The majority of type-1 clasts occur in layers also rich in garnet (Fig. 4a). Finer-grained recrystallized sillimanite, here termed "daughter" grains, occur adjacent to serrated margins and primarily within strain shadows of larger sillimanite clasts (Fig. 5a, b). Grain size statistics of subgrains and daughter grains associated with the same parent porphyroclast yield similar results: average grain diameters between $19 \mu \mathrm{m}$ (daughter grains) and $28 \mu \mathrm{m}$ (subgrains) within a range of $\sim 2 \mu \mathrm{m}$ to $150 \mu \mathrm{m}$. The general similarity in grain size in addition to the spatial occurrence of daughter grains adjacent to scalloped margins and primarily within strain shadows of parent sillimanite porphyroclasts suggests a genetic link between subgrains and daughter grains. Daughter grains may be a more evolved form of subgrains; with sufficient rotation, a subgrain boundary becomes a (daughter) grain boundary. Additionally, fracturing may have also played a subsidiary role (to the dominant subgrain rotation process) in the separation of the parent porphyroclast from its daughter grains. And, as deformation proceeded, daughter grains are farther separated from their parent clasts and matrix quartz and feldspar fill the void of separation.

Type-1 sillimanite also occurs in samples 03M13 and 03M166B. However, unlike samples 10W-098A and 11L-136B, sillimanite in samples 03M13 and 03M166B commonly displays undulose extinction but only locally displays kink bands and subgrain microstructure. In sample $03 \mathrm{M} 13$, aggregates of subhedral blocky to elongate sillimanite prisms ( $\sim 150$ to 400 
$\mu \mathrm{m})$ lack any shape preferred orientation and occur in matrix layers with garnet (Fig. 5c).

Type-1 sillimanite in sample 03M166B is coarse-grained (up to a few $\mathrm{mm}$ ) and occurs in thick layers (several $\mathrm{mm}$ ) consisting almost entirely of sillimanite.

Type-2 sillimanite porphyroclasts in sample 10W-098A notably lack the subgrain microstructure that is characteristic of type-1 sillimanite (Fig. 5b, e). Type-2 clasts also have a blockier shape compared to type-1 clasts though still show a lineation-parallel shape preferred orientation (Fig. 5b, e). Long axes of type-2 clasts are $\sim 500 \mu \mathrm{m}$, generally smaller than type-1 parent porphyroclasts $(\leq 3 \mathrm{~mm})$ though significantly larger than subgrains within and daughter grains adjacent to type-1 clasts (average diameter $\leq 28 \mu \mathrm{m}$ ). Moreover, type-2 clasts generally occur in matrix domains surrounded by quartz and feldspar (Fig. 4a). Thus, the generally discrete spatial distribution paired with the large discrepancy in grain size between type-2 clasts and subgrains and daughter grains associated with type-1 clasts suggests that type-2 clasts represent a separate generation from type-1 clasts.

Type-2 sillimanite in sample $03 \mathrm{M} 13$ is characterized by fine-grained elongate sillimanite prisms with a lineation-parallel long-axis of $\leq 200 \mu \mathrm{m}$ that occur in quartzofeldspathic ribbon mylonite layers (Fig. 5d). Type-2 sillimanite in hydrous felsic amphibolite samples 03M166B and 04G-029B is characterized by prismatic sillimanite fish $(\leq 1 \mathrm{~cm})$ that are locally bent and display undulose extinction and kink bands, but subgrain microstructure is absent (Fig. 5f, g).

Type-3 sillimanite in hydrous felsic amphibolite samples 03M166B and 04G-029B is morphologically distinct from the other two types of sillimanite. Type-3 sillimanite is characterized by fine-grained ( $<15 \mu \mathrm{m}$ thick) euhedral needles developed immediately adjacent to type-2 sillimanite, either as foliation-parallel tails or adjacent to serrated margins 
(Fig. 5f, g). Type-3 sillimanite is also locally developed in the matrix with a shape preferred orientation parallel to the stretching lineation. Asymmetry of sillimanite porphyroclasts (type2) and tails (type-3; Fig. 5f, g) in addition to the presence of foliation-parallel sillimanite needles in the matrix (type-3) indicate dextral synkinematic deformation and growth of sillimanite.

\section{EBSD analyses}

\section{Methods}

Electron backscatter diffraction (EBSD) analyses were conducted on sillimanite and quartz fabrics in samples of anhydrous felsic granulite and hydrous felsic amphibolite. The methods used for sample preparation, data acquisition settings, and data collection and processing similarly follow those of Halfpenny et al. (2006) and Warren et al. (2008). All analyses were conducted at the University of Colorado-Boulder Nanomaterials Characterization Facility. Standard $(30 \mu \mathrm{m})$ kinematic (X-Z plane) polished thin sections were prepared for analysis by polishing with $0.02 \mu \mathrm{m}$ colloidal silica for at least one hour. Data were collected on a JEOL JSM-6480LV SEM with an EBSD detector and HKL Technology's Channel 5 software package. The EBSD patterns were collected using a $20 \mathrm{kV}$ acceleration voltage under low vacuum, 13 $\mathrm{Pa}$ (to prevent charging). An area of $\sim 20 \times 30 \mathrm{~mm}$ was mapped in all sample thin sections for mineral phases and crystallographic orientations at 40x magnification and 100-200 $\mu \mathrm{m}$ step size. High resolution ( 2 um step size) EBSD maps were collected for more detailed textural analysis of sillimanite (Fig. 6a, 7a, 9a, 10a).

Sillimanite has an orthorhombic crystal structure and crystallizes long prismatic parallel to [001]. Previous work has identified [001] as an important component in sillimanite 
deformation (e.g., Lambregts and van Roermund, 1990; Goergen et al., 2008). Thus, sillimanite [001] texture maps (Fig. 6a, 7a, 9a, 10a) were generated in order to illustrate the deviation of [001] from the shear direction $(\mathrm{X})$. In these figures, the gradational color scale represents the degree of misorientation: a $0^{\circ}$ misorientation or parallelism with $\mathrm{X}$ is shown in red and a specific maximum angle relative to $\mathrm{X}$ is shown in yellow. Importantly, in an effort to best illustrate single-grain [001] relative misorientation angles in different samples, the maximum misorientation angle for anhydrous felsic granulite $\left(55^{\circ}\right)$ is significantly larger than that for hydrous felsic amphibolite $\left(35^{\circ}\right)$. Y-axes of corresponding profiles show the relative misorientation between points along a dashed line across a single sillimanite grain (Fig. 6b, 7b, 9b, 10b). Corresponding histograms show the relative frequency of sillimanite [001] misorientation with respect to X (Fig. 6c, 7c, 9c, 10c).

Pole figures and inverse pole figures for sillimanite orientations are shown in Fig. 8 for anhydrous felsic granulite and Fig. 11 for hydrous felsic amphibolite. Inverse pole figures show the orientation of individual grains with respect to the shear direction $(\mathrm{X})$ and normal to the shear plane (Z). Subsets of EBSD data were generated for type-1, -2 , and/or -3 sillimanite in samples 10W-098A, 03M13, and 03M166B based on specific characteristics defined in the previous section. Quartz [001] pole figures are shown in Fig. 12.

\section{Sillimanite}

\section{Anhydrous felsic granulite 10W-098A, 11L-136B, $03 \mathrm{M} 13$}

Textural analysis of sillimanite from anhydrous felsic granulite (10W-098A, 11L-136B, 03M13) shows variable scatter around broad [001] maxima approximately parallel to X (Fig. 8). These data indicate (a) a preferential alignment of [001] sub-parallel to the shear direction 
and (b) the importance of [001]-parallel slip in sillimanite with intracrystalline deformation.

The latter is consistent with deformation experiments on sillimanite (Goergen et al., 2008) and studies of naturally deformed sillimanite (Lambregts and van Roermund, 1990).

For simplicity, we use the term "subgrain" for all sillimanite within a parent porphyroclast with subgrain microstructure, even if the misorientation angle at the subgrain boundary exceeds the typical cut-off of $10^{\circ}$ (e.g., White, 1977, for quartz). As suggested above, the statistically similar grain size of subgrains and daughter grains suggests a genetic link and development by the same deformation mechanism. Thus, we treat data from subgrains and daughter grains similarly in this section, although this subject will be discussed later.

Subgrain boundaries within sillimanite porphyroclasts in 11L-136B and 10W-098A (type-1) are characterized by a color contrast in the [001] texture map and discrete steps in the profile (Fig. 6a, b; 7a, b). A variance in [001] relative misorientation angles $\left(\sim 7-40^{\circ}\right)$ between adjacent subgrains and a wide distribution of [001] orientations around X (Fig. 6c, d; 7c, d) are observed in both anhydrous samples (10W-098A type-1 and 11L-136B). Particularly in 11L-136B, the maximum density of points in the X-section are oriented $\sim 35^{\circ}$ to [001] (Fig. 7d) and [001] orientations are misoriented by between $20^{\circ}$ and $\geq 55^{\circ}$ relative to $X$ (Fig. $7 \mathrm{C}$ ). This variance demonstrates that subgrains have rotated relative to one another. There is also abundant evidence, particularly in 10W-098A type-1 sillimanite, that suggests that subgrain [001] orientations are rotating toward a common direction parallel to X: (a) the broader likeness in color across the [001] texture map (Fig. 6a), (b) the majority of [001] orientations $\leq 35^{\circ}$ to $X$ (Fig. 6c), and, (c) development of [001] parallel to X (Fig. 6d). Also, given that daughter grains are likely a more evolved form of subgrains, the generally closer alignment to X of [001] axes 

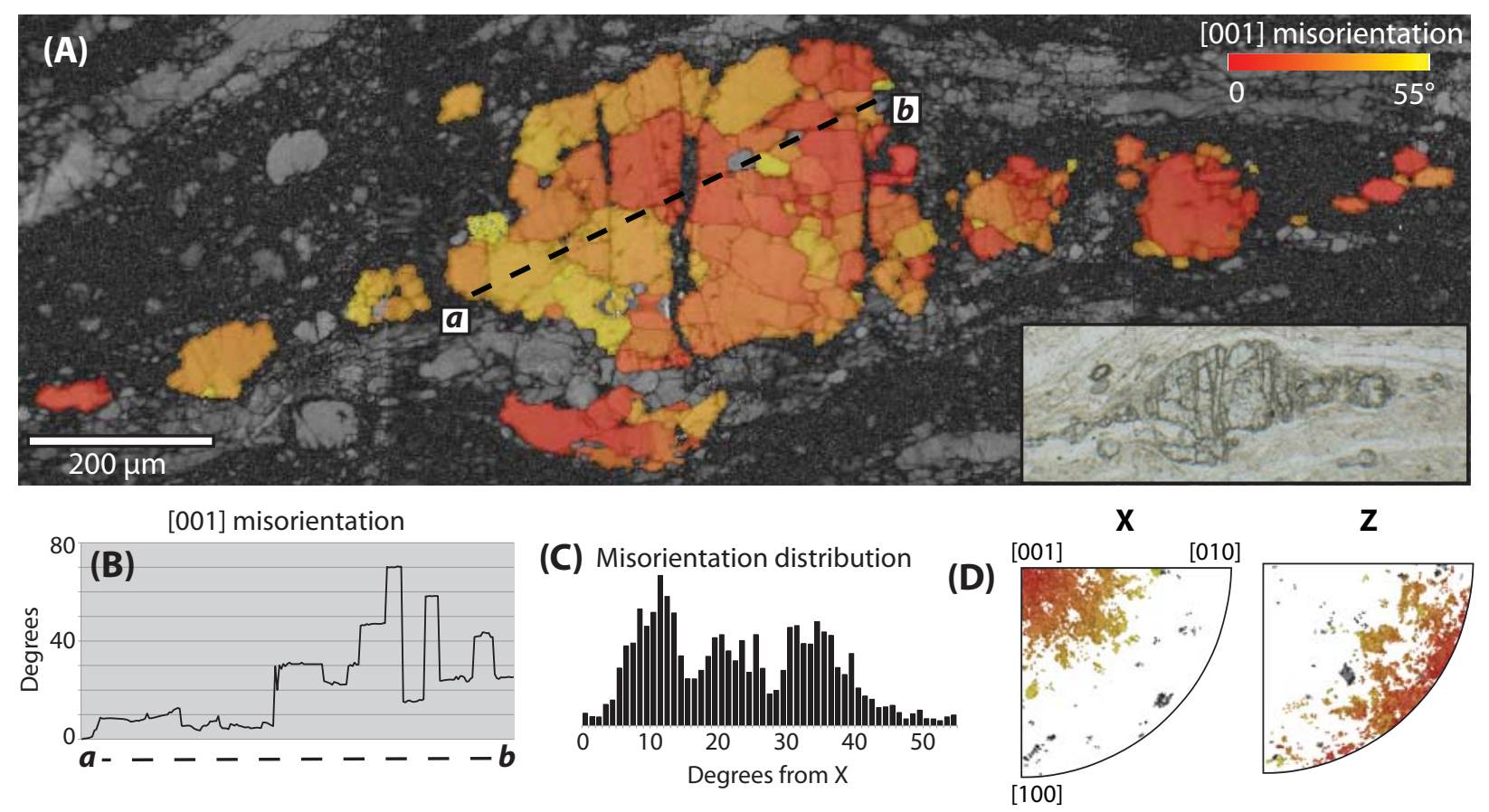

Fig. 6. Anhydrous felsic granulite 10W-098A (type-1) sillimanite porphyroclast. (A) [001] EBSD texture map overlain on band contrast image. Gradational color scale represents degree of [001] misorientation relative to $\mathrm{X}$ (horizontal): $0^{\circ}$ misorientation (X-parallel) shown in red; $55^{\circ}$ misorientation (maximum) shown in yellow. Dashed line indicates $a-b$ profile traverse in (B). Inset is photomicrograph of same area. (B) Profile a-b showing [001] misorientation relative to the first point (a) along the dashed line to (b). (C) Histogram showing relative frequency of [001] misorientation angle with respect to $X$. (D) Inverse pole figures (upper hemisphere) for all points $(n=45316)$ shown in (A). Same color scale as in (A). Gray points in (D) are misoriented $>55^{\circ}$. 

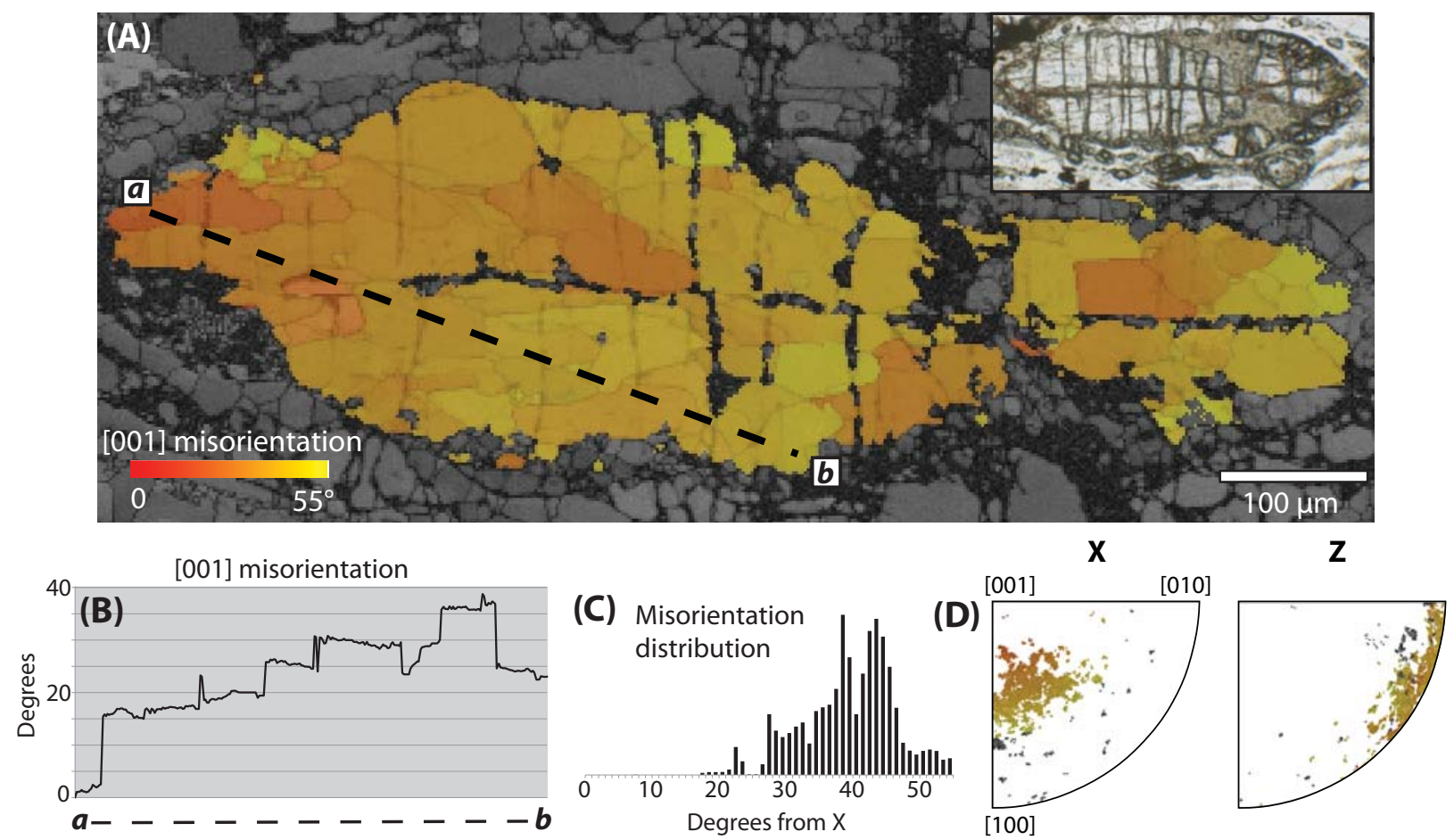

Fig. 7. Anhydrous felsic granulite $11 \mathrm{~L}-136 \mathrm{~B}$ sillimanite porphyroclast. (A) [001] EBSD texture map overlain on band contrast image. Gradational color scale represents degree of [001] misorientation relative to $X$ (horizontal): $0^{\circ}$ misorientation (X-parallel) shown in red; $55^{\circ}$ misorientation (maximum) shown in yellow. Dashed line indicates $a-b$ profile traverse in (B). Inset is photomicrograph of same area. (B) Profile a-b showing [001] misorientation relative to the first point (a) along the dashed line to (b). (C) Histogram showing relative frequency of [001] misorientation angle with respect to X. (D) Inverse pole figures (upper hemisphere) for all points $(n=29933)$ shown in $(A)$. Same color scale as in $(A)$. Gray points in (D) are misoriented $>55^{\circ}$. 
of daughter grains compared to [001] axes of subgrains (Fig. 6a) suggests that daughter grains have recrystallized in a preferential orientation with [001] parallel to X. It should also be noted that the largest relative [001] misorientation angles $\left(\leq 55^{\circ}\right)$ correspond with fractures in sillimanite (Fig. 6a, b), suggesting that fractures locally enhance the misorientation angle between grains.

Statistically, type-1 sillimanite porphyroclasts in 03M13 show a minor [100] maximum slightly oblique to Z, but significant scatter in the data indicates mostly variable orientations of [100] and [010] (Fig. 8). However, sillimanite porphyroclasts with subgrain microstructure (10W-098A type-1, 11L-136B) show minor [100] and [010] maximum distributions slightly inclined to Z (Fig. 8). In these samples, scatter of [010] oblique to Z reveals a weak girdle distribution, whereas significant scatter of [100] both oblique to $Z$ and variably rotated with respect to $Z$ displays a much weaker pattern. The maximum density of points in the Z-sections (Fig. 8) is scattered between [100] and [010], suggesting that that both (100) and (010) may be active for slip. Thus, the preferred orientation of sillimanite porphyroclasts with subgrain microstructure (10W-098A type-1, 11L-136B) may be interpreted to have formed by intracrystalline plastic deformation by both (010)[001] and (100)[001] slip systems. It may also be worth noting that quantitative analysis of a single sillimanite porphyroclast in $11 \mathrm{~L}-136 \mathrm{~B}$ revealed that (010) may be more favorable for slip than (100) (Fig. 7d). Alternatively, the lack of a preferred orientation of [100] and [010] in 03M13 type-1 sillimanite may be attributed to negligible intracrystalline deformation and possibly indicative of nucleation in a variable orientation or rigid rotation of the crystals. 
Sillimanite, anhydrous felsic granulite

[100]

[010]

10W-098A Type-1 $(\mathrm{n}=705)$
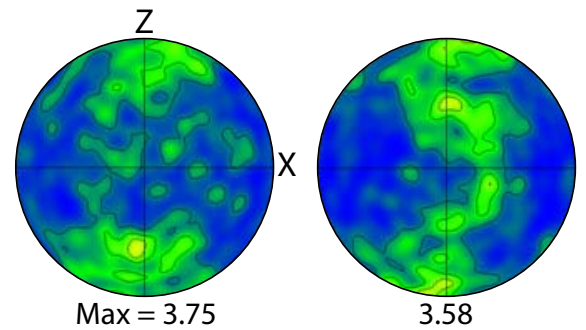

10W-098A Type-2 $(\mathrm{n}=111)$
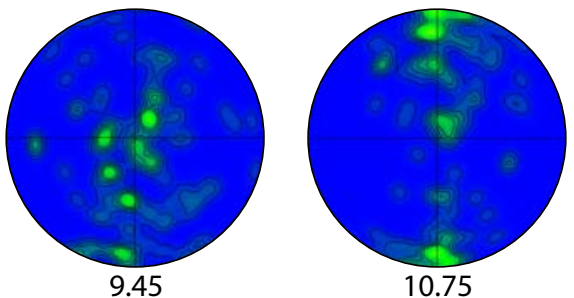

11L-136B $(\mathrm{n}=1975)$

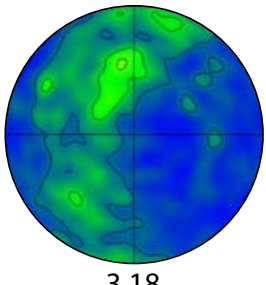

3.18

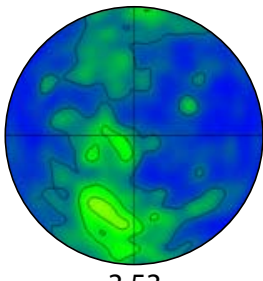

3.53

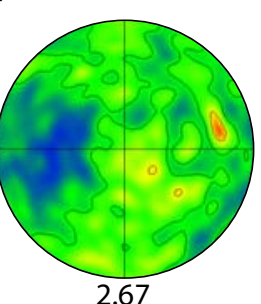

03M13 Type-2 $(n=322)$
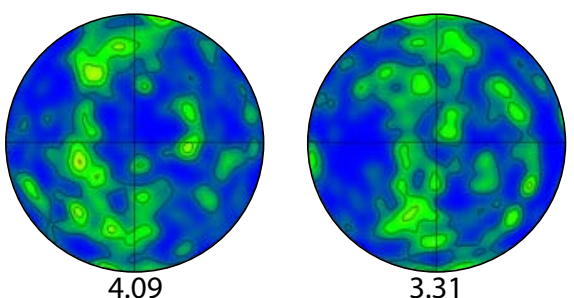

[001]
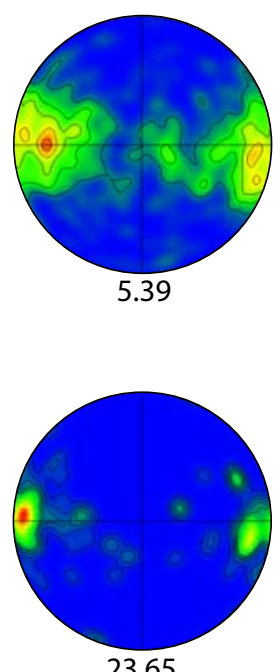

23.65

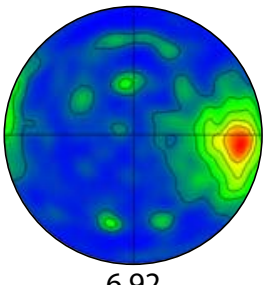

6.92
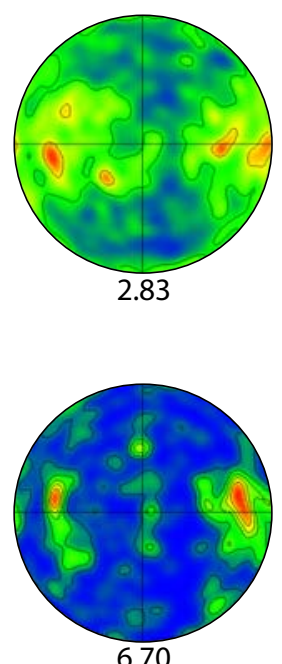

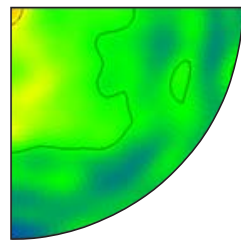

2.27

$\mathbf{X}$
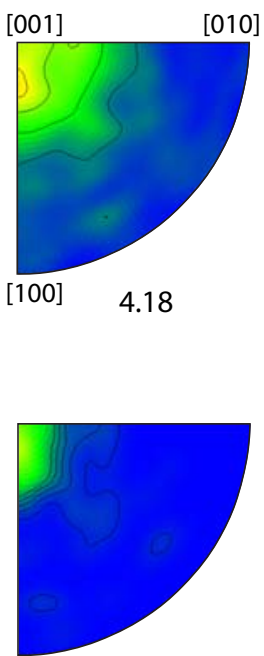

14.03

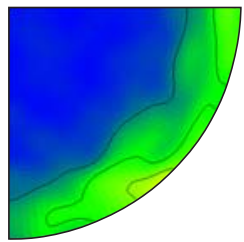

3.57

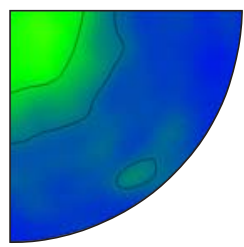

2.85

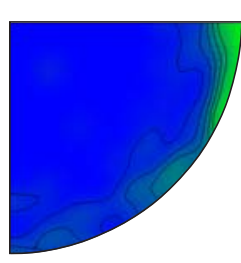

7.17

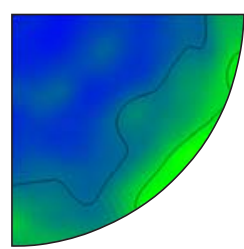

2.51

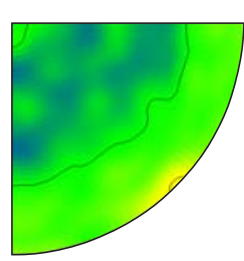

2.03

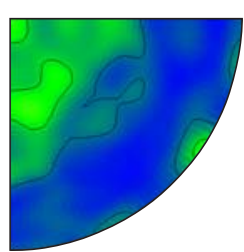

2.81
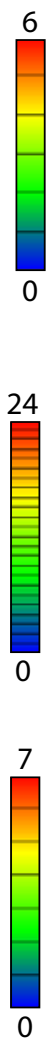

Fig. 8. Sillimanite pole figures (lower hemisphere) and inverse pole figures (upper hemisphere) for anhydrous felsic granulite (10W-098A, 11L-136B, and 03M13) in a kinematic (X-Z) reference frame, relative to $S_{2}$. Calculated using one point per grain. Contours are multiples of a uniform distribution (MUD). Maximum MUD values are identified below each pole figure. 
Type-2 sillimanite porphyroclasts in $10 \mathrm{~W}-098 \mathrm{~A}$ show a strong [010] maximum parallel to $Z$ and a greater obliquity of [100] relative to Z (Fig. 8). Additionally, points cluster around [010] with minor scatter toward [100] in the Z-section (Fig. 8). Alternatively, both [100] and [010] show much more scatter in 03M13 type-2 sillimanite than the same axes for 10W-098A type-2 sillimanite (Fig. 8). Thus, assuming negligible intracrystalline deformation, type-2 sillimanite in 10W-098A may have nucleated or rigidly rotated in an orientation with [001] and [010] parallel to $X$ and $Z$, respectively. In contrast, despite the lineation-parallel shape preferred orientation of type- 2 sillimanite in $03 \mathrm{M} 13$, the crystals may have nucleated in relatively random crystallographic orientations.

\section{Hydrous felsic amphibolite 04G-029B, 03M166B}

Textural analysis of sillimanite from hydrous felsic amphibolite (04G-029B, 03M166B) reveals remarkably different results than that for anhydrous granulite. The most notable distinctions observed in sillimanite from hydrous amphibolite include: (1) the lack of subgrain microstructure and, (2) the presence of morphologically distinct euhedral sillimanite prisms at the tails of and adjacent to serrated margins of parent porphyroclasts (Fig. 9a, 10a).

Instead of discrete [001] misorientations across subgrain boundaries as observed in anhydrous felsic granulite, a gradation of [001] misorientations or remarkably consistent [001] orientations are evident in sillimanite in 03M166B and 04G-029B, respectively (Fig. 9a, 10a). In 03M166B sillimanite, other than one abrupt change in relative [001] misorientation $\left(\sim 20^{\circ}\right)$ that corresponds with a fracture, this gradation in misorientation is demonstrated by the $\sim 20^{\circ}$ total [001] misorientation from porphyroclast center to tail (Fig. 9b). Further, [001] orientations range from $\leq 30^{\circ}$ relative to $X$ with a systematic scatter toward X (Fig. 9c, d) 


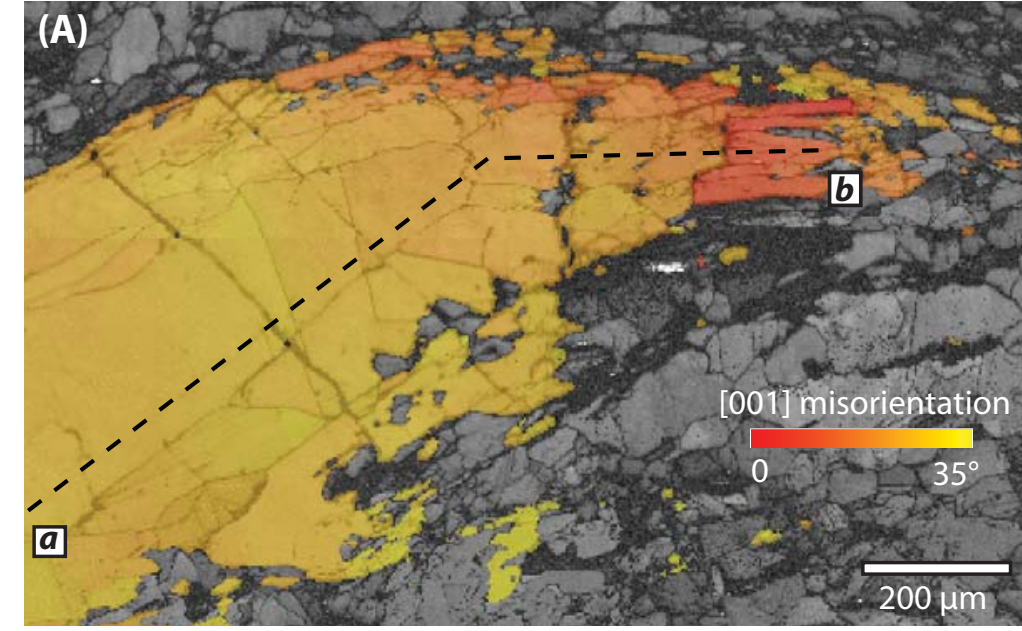

Fig. 9. Hydrous felsic amphibolite 03M166B sillimanite porphyroclast. (A) [001] EBSD texture map overlain on band contrast image. Gradational color scale represents degree of [001] misorientation relative to $X$ (horizontal): $0^{\circ}$ misorientation (X-parallel) shown in red; $35^{\circ}$ misorientation (maximum) shown in yellow. Dashed line indicates $a-b$ profile traverse in (B). Photomicrograph of same area shown in Fig. 5f. (B) Profile $a-b$ showing [001] misorientation relative to the first point (a) along the dashed line to (b). (C) Histogram showing relative frequency of [001] misorientation angle with respect to $X$. (D) Inverse pole figures (upper hemisphere) for all points $(n=63954)$ shown in $(A)$. Same color scale as in (A). Gray points in (D) are misoriented $>35^{\circ}$.
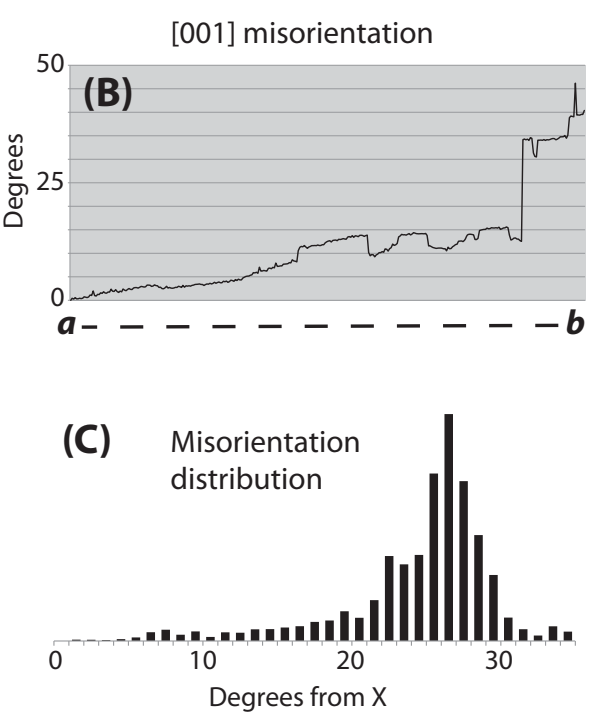

(D)

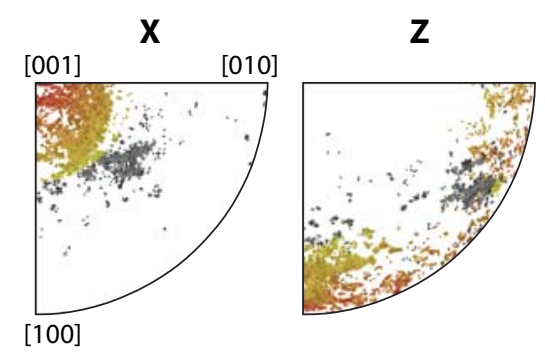




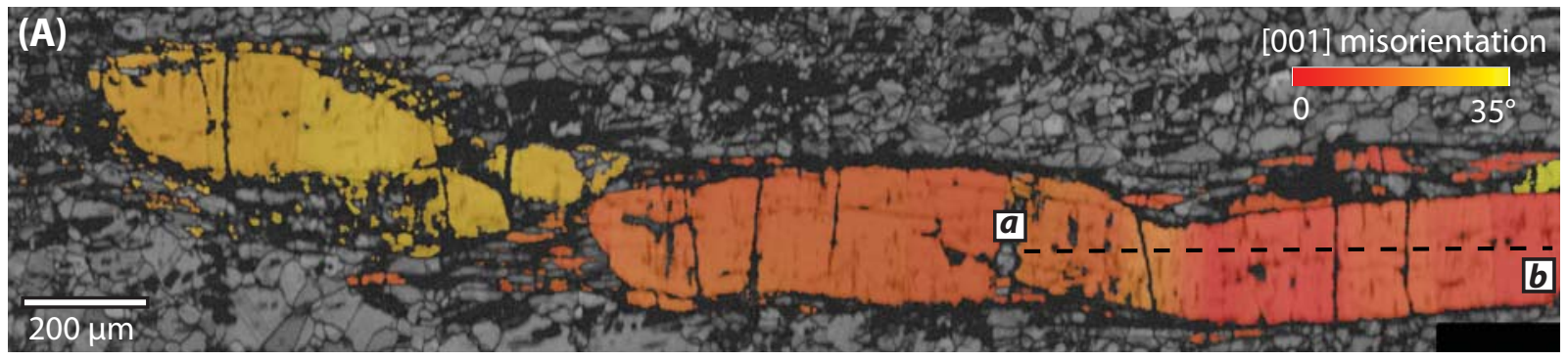

[001] misorientation

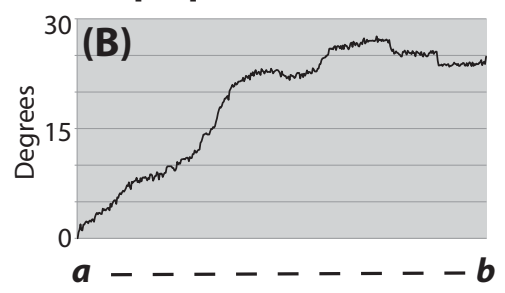

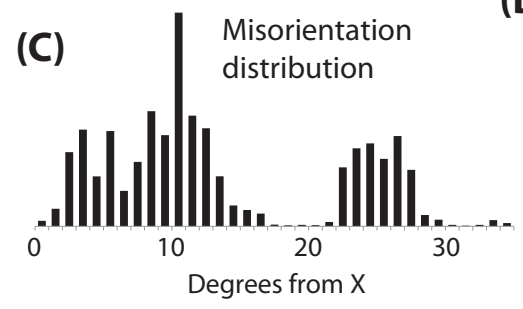

(D)

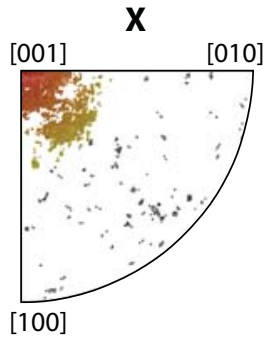

$\mathbf{Z}$

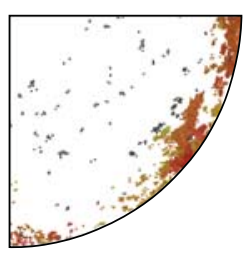

Fig. 10. Hydrous felsic amphibolite 04G-029B sillimanite porphyroclasts. (A) [001] EBSD texture map overlain on band contrast image. Gradational color scale represents degree of [001] misorientation relative to $X$ (horizontal): $0^{\circ}$ misorientation (X-parallel) shown in red; $35^{\circ}$ misorientation (maximum) shown in yellow. Dashed line indicates a-b profile traverse in (B). Photomicrograph of same area shown in Fig. 5g. (B) Profile a-b showing [001] misorientation relative to the first point (a) along the dashed line to (b). (C) Histogram showing relative frequency of [001] misorientation angle with respect to $X$. (D) Inverse pole figures (upper hemisphere) for all points $(n=97992)$ shown in $(A)$. Same color scale as in (A). Gray points in (D) are misoriented $>35^{\circ}$. 
suggesting that dislocation glide is operating as the type-2 sillimanite porphyroclast is gradually bent and [001] is increasingly aligned with $X$ toward the tail of the porphyroclast. Other than minor bending, type-2 sillimanite porphyroclasts in hydrous felsic amphibolite 04G-029B are remarkably consistent in [001] orientation throughout the entire grain and into the adjacent type-3 euhedral needles (Fig. 10a, b, c). However, separate sillimanite porphyroclasts may differ slightly in [001] orientation relative to one another, with [001] obliquity relative to $X$ ranging between $20-30^{\circ}$ in some clasts to $\leq 15^{\circ}$ in others (Fig. $10 a, c, d$ ). Euhedral type-3 sillimanite at the tails of porphyroclasts notably tend to develop in a preferential orientation with [001] parallel to the shear direction (Fig. 9a; 10a). However, sillimanite needles in strain shadows and/or adjacent to serrated margins of porphyroclasts tend to inherit the crystallographic orientation of the immediately adjacent parent clast (Fig. 9a; 10a). This suggests that recrystallization of type-3 sillimanite may have been accommodated by deformation-induced dissolution and reprecipitation of alumino-silicate material either: (1) as foliation-parallel tails with [001] parallel to X; or, (2) syntaxially relative to the adjacent parent material.

Sub-parallelism of [001] with X is also evident statistically in 04G-029B and 03M166B type3 sillimanite (Fig. 11). These data indicate a preferential alignment of sillimanite [001] parallel to the shear direction. Alternatively, type-1 sillimanite (coarse-grained with local subgrain microstructure) in 03M166B shows variable scatter around broad maxima of [001] approximately parallel to X (Fig. 11), similar to results for sillimanite in anhydrous granulite discussed above. Sillimanite in 04G-029B and type-1 sillimanite in 03M166B show [100] and [010] maxima slightly inclined to $Z$ with scatter generally toward $Y$, revealing weak girdle 
Sillimanite, hydrous felsic amphibolite

[100] [010]

03M166B Type-1 $(n=990)$
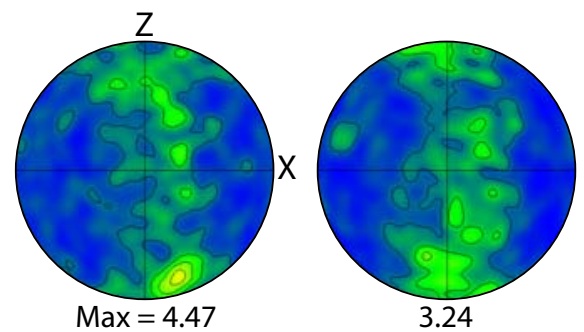

03M166B Type-3 $(n=4732)$

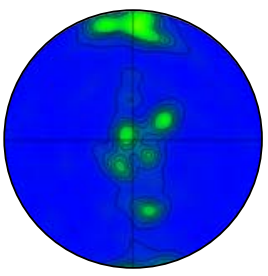

11.15

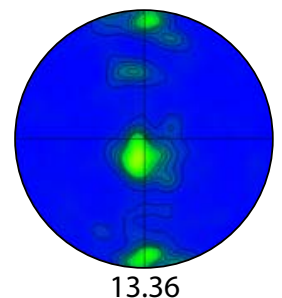

04G-029B $(n=469)$

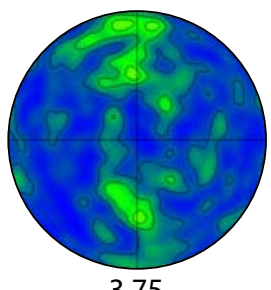

3.75

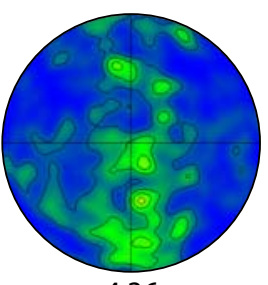

4.36

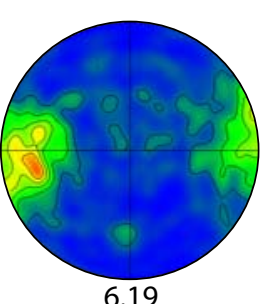

6.19

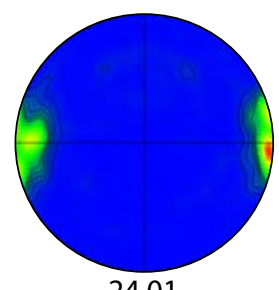

24.01

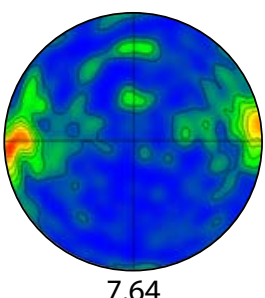

7.64
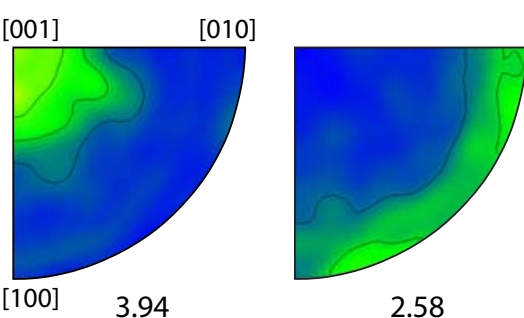

2.58

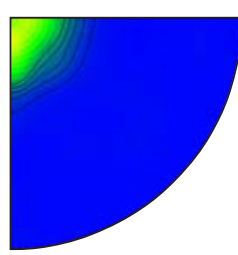

15.69

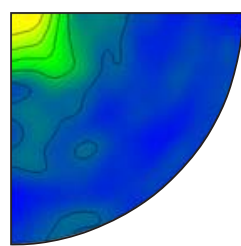

5.49

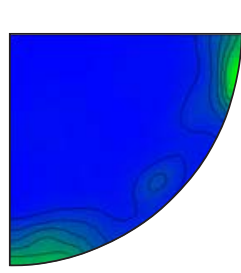

8.35

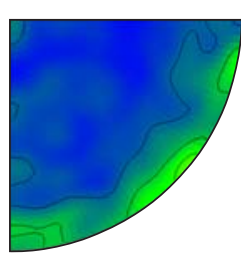

3.51

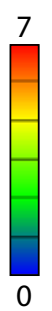

Fig. 11. Sillimanite pole figures (lower hemisphere) and inverse pole figures (upper hemisphere) for hydrous felsic amphibolite (03M166B and 04G-029B) in a kinematic (X-Z) reference frame, relative to $S_{2}$. Calculated using one point per grain. Contours are multiples of a uniform distribution (MUD). Maximum MUD values are identified below each pole figure. 
distributions (Fig. 11). Points also scatter between [100] and [010] in the Z-sections (Fig. 11). Type-3 sillimanite in 03M166B shows much tighter maxima of [100] and [010] parallel to Z (Fig. 11). It may also be worth noting that detailed quantitative analysis of sillimanite porphyroclasts revealed a preferential orientation of (100)[001] in 03M166B (Fig. 9d) and (010)[001] in 04G-029B (Fig. 10d). Together, these results suggest that: (1) intracrystalline deformation in 03M166B type-1 sillimanite may have been accommodated by both (100)[001] and (010)[001] slip systems, similar to results for anhydrous felsic granulite; (2) type-3 sillimanite in 03M166B recrystallized with [001] parallel to the shear direction and with either (100) or (010) parallel to the shear plane; and, (3) sillimanite in 04G-029B recrystallized with [001] parallel to the shear direction, perhaps with a slight tendency of (010) parallel to the shear plane.

\section{Quartz}

Quartz [001] orientations have been widely used to qualitatively estimate the temperature of deformation (e.g., Schmid \& Casey, 1986). Further, a pattern asymmetry in quartz [001] has often been used to deduce sense of shear (e.g., Schmid \& Casey, 1986). Here, quartz [001] orientations in both anhydrous felsic granulite and hydrous felsic amphibolite are examined in order to elucidate the temperature of deformation and if possible, the kinematics.

The quartz [001] crystallographic preferred orientations observed in anhydrous felsic granulite suggest that deformation is accommodated by dislocation creep (Fig. 12). Quartz in anhydrous felsic granulite sample 10W-098A shows an asymmetric [001] girdle distribution with a maximum distribution slightly oblique to $\mathrm{Y}$ in the $\mathrm{Z}$ direction (Fig. 12), which is indicative of rhomb and prism <a> slip (e.g., Passchier \& Trouw, 1996). The pattern also 
Quartz [001]
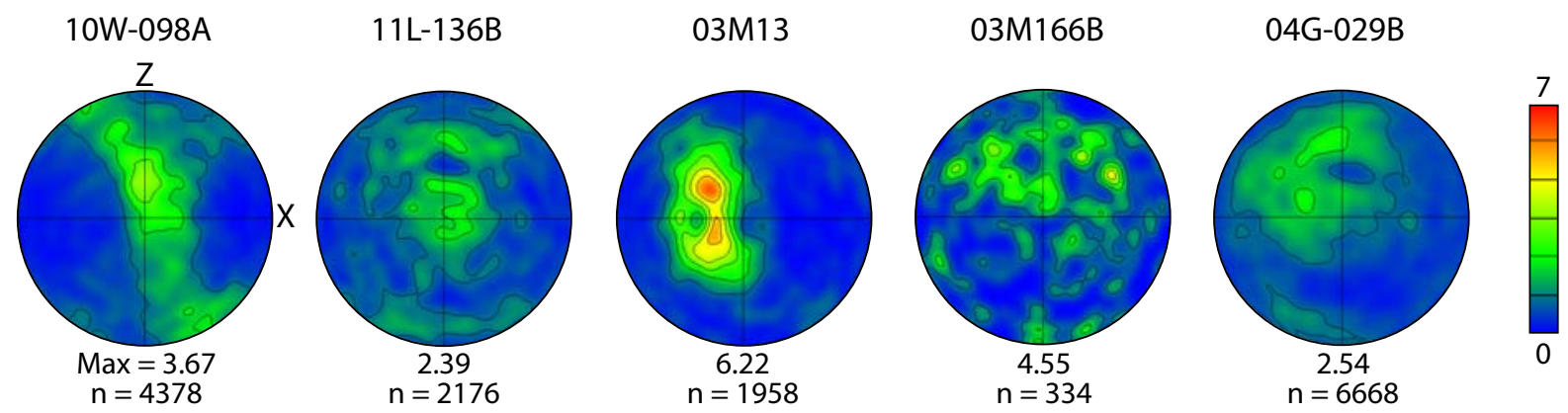

Fig. 12. Quartz [001] pole figures (lower hemisphere) for anhydrous felsic granulite (10W-098A, 11L-136B, and 03M13) and hydrous felsic amphibolite (03M166B and 04G029B) in a kinematic (X-Z) reference frame, relative to $S_{2}$. Calculated using one point per grain. Contours are multiples of a uniform distribution (MUD). Maximum MUD values are identified below each pole figure. 
suggests sinistral shear under relatively high-temperature conditions (e.g., Passchier \& Trouw, 1996), which is consistent with field evidence for sinistral kinematics and other microstructural evidence for high-temperature deformation (i.e., subgrain microstructure in sillimanite). However, the ultramylonitic fabric characteristic of sample 10W-098A generally makes determining kinematics elusive; accordingly, these data provide useful information on the kinematics (sinistral) under which the ultramylonite formed. Quartz [001] in the other two samples of anhydrous felsic granulite, $11 \mathrm{~L}-136 \mathrm{~B}$ and $03 \mathrm{M} 13$, show variable scatter around maxima sub-parallel to $Y$ (Fig. 12), which is indicative of prism <a > slip (e.g., Passchier \& Trouw, 1996). A quartz [001] maximum distribution parallel to $Y$ has also been documented in other samples in the region (Ji et al., 1993) and is typical of high-temperature deformation (e.g., Schmid \& Casey, 1986). Alternatively, quartz in hydrous felsic amphibolite samples 03M166B and 04G-029B shows highly variable scatter in [001] orientations and thus, essentially lacks any discernible pattern (Fig. 12). This may be a manifestation of strain partitioning, whereby the micas are accommodating the bulk of the strain and quartz is hardened and essentially undeformed (e.g., Tullis, 2002). Alternatively, incomplete realignment of crystallographic axes from a pre-existing fabric may account for the pattern randomization (e.g., Warren et al., 2008). 


\section{MONAZITE GEOCHRONOLOGY: ANHYDROUS FELSIC GRANULITE}

Monazite is abundant in anhydrous felsic granulite 10W-098A and 03M13, though rare in 11L-136B. Data from these three anhydrous felsic granulite samples are presented and five distinct populations are divided based on composition, textural setting, morphology, and age. Also, the populations designated here are consistent with the monazite populations (1 through 5) that were designated in Mahan et al. (2006b) as summarized here: Populations 1 through 3 contain progressively lower $Y$ concentrations (from $>1.0$ wt $\%$ to $<1000$ ppm) and yield progressively younger dates in the range of 2.56 to $2.50 \mathrm{Ga}$. Population 4 also contains low $Y$ concentrations and has a weighted mean from sample 03M166B of $1915 \pm 23 \mathrm{Ma}$. With new data presented here, sub-populations are delineated in populations 1 (1a-1c) and 4 (4a4b) of Mahan et al. (2006b).

\section{Analytical methods and procedures}

The methods used for evaluating and analyzing monazite data follow after those of Williams \& Jercinovic (2002) and Jercinovic \& Williams (2005). All analyses were conducted at the University of Massachusetts-Amherst electron microprobe facility. X-ray composition maps were generated using the 5-spectrometer Cameca SX-50 electron microprobe. The occurrence, distribution, and textural setting of monazite were first evaluated using full thin section X-ray maps: Ce X-ray maps were used to identify monazite and major element (i.e., Ca

or Mg) X-ray maps were used to establish the overall texture. High resolution X-ray maps of $Y$, Th, U, Ca, and Si were generated for each monazite grain.

Quantitative trace element analyses were conducted on the 5-spectrometer Cameca SX100 Ultrachron. Analytical conditions are given in Table 2. Quantitative major element 
Table 2. Monazite trace element compositions and calculated dates.

\begin{tabular}{|c|c|c|c|c|c|c|c|c|c|c|c|c|c|c|}
\hline \multirow{2}{*}{$\begin{array}{c}\text { Date } \\
\text { analyzed }\end{array}$} & \multirow[t]{2}{*}{ Grain } & \multirow[t]{2}{*}{ Setting* } & \multirow[t]{2}{*}{ Pop } & \multicolumn{8}{|c|}{ Trace Element Concentrations in ppm } & \multirow[t]{2}{*}{$\mathrm{N}$} & \multirow{2}{*}{$\begin{array}{l}\text { Date } \\
\text { (Ma) }\end{array}$} & \multirow{2}{*}{$\begin{array}{c}2 \sigma \\
(\mathrm{Ma})\end{array}$} \\
\hline & & & & $Y$ & $1 \sigma$ & Th & $1 \sigma$ & $\mathrm{Pb}$ & $1 \sigma$ & $\mathrm{U}$ & $1 \sigma$ & & & \\
\hline \multicolumn{15}{|c|}{ Anhydrous felsic granulite 10W-098A } \\
\hline $2 / 6 / 2012$ & m16 & pi-s2 & $4 a$ & 194 & 23 & 2391 & 58 & 1396 & 18 & 3533 & 25 & 6 & 1925 & 28 \\
\hline $2 / 6 / 2012$ & m3 & $\mathrm{i}-\mathrm{g}$ & $4 a$ & 449 & 47 & 86589 & 1750 & 8803 & 193 & 3148 & 46 & 6 & 1924 & 26 \\
\hline $2 / 6 / 2012$ & m31 & pi-g & $4 a$ & 146 & 31 & 27053 & 492 & 3289 & 52 & 2676 & 46 & 6 & 1909 & 22 \\
\hline $2 / 6 / 2012$ & m4 & m-lo-str & $4 a$ & 310 & 79 & 7325 & 327 & 1628 & 57 & 2966 & 95 & 5 & 1905 & 32 \\
\hline $2 / 6 / 2012$ & $\mathrm{~m} 22$ & m-myl & $4 a$ & 213 & 39 & 13715 & 1617 & 2098 & 145 & 2635 & 90 & 5 & 1916 & 28 \\
\hline $2 / 6 / 2012$ & $\mathrm{~m} 7$ & $\mathrm{i}-\mathrm{s} 1$ & $4 b$ & 343 & 27 & 111404 & 2011 & 10611 & 191 & 2575 & 32 & 7 & 1886 & 14 \\
\hline $2 / 6 / 2012$ & $\mathrm{~m} 7$ & $\mathrm{i}-\mathrm{s} 1$ & $4 b$ & 308 & 47 & 140448 & 4944 & 13258 & 492 & 2682 & 47 & 9 & 1895 & 20 \\
\hline $2 / 6 / 2012$ & $\mathrm{~m} 3$ & $i-g$ & $4 b$ & 616 & 58 & 59378 & 833 & 6453 & 72 & 3766 & 56 & 3 & 1891 & 10 \\
\hline $2 / 6 / 2012$ & m31 & pi-g & $4 b$ & 224 & 95 & 17775 & 475 & 2190 & 63 & 1955 & 173 & 13 & 1882 & 42 \\
\hline $2 / 6 / 2012$ & $\mathrm{~m} 15$ & m-myl & $4 b$ & 252 & 33 & 5313 & 714 & 1233 & 61 & 2343 & 101 & 3 & 1891 & 14 \\
\hline $2 / 6 / 2012$ & $\mathrm{~m} 10$ & i-s1 & $4 b$ & 675 & 40 & 20760 & 690 & 3161 & 18 & 4190 & 240 & 3 & 1873 & 16 \\
\hline $2 / 6 / 2012$ & $\mathrm{~m} 28$ & m-lo-str & $4 b$ & 239 & 15 & 497 & 77 & 956 & 55 & 2796 & 170 & 5 & 1889 & 30 \\
\hline $2 / 6 / 2012$ & m13 & i-s1 & $4 b$ & 843 & 49 & 1034 & 68 & 1203 & 36 & 3402 & 122 & 4 & 1891 & 44 \\
\hline \multicolumn{15}{|c|}{ Anhydrous felsic granulite 11L-136B } \\
\hline $2 / 6 / 2012$ & m5 & m-myl & $4 b$ & 126 & 22 & 114174 & 4371 & 10213 & 473 & 609 & 46 & 4 & 1887 & 40 \\
\hline $2 / 6 / 2012$ & m5 & m-myl & $4 b$ & 161 & 18 & 20131 & 769 & 1887 & 75 & 406 & 15 & 6 & 1876 & 36 \\
\hline \multicolumn{15}{|c|}{ Anhydrous felsic granulite $03 \mathrm{M} 13$} \\
\hline $2 / 6 / 2012$ & m18 & i-g-rim & $1 \mathrm{a}$ & 7152 & 1008 & 19361 & 2634 & 3909 & 387 & 2910 & 359 & 3 & 2638 & 26 \\
\hline $6 / 20 / 2005$ & $\mathrm{~m} 1$ & i-g-core & $1 a$ & 6887 & 1343 & 21017 & 3778 & 4398 & 649 & 3540 & 1184 & 6 & 2619 & 118 \\
\hline $2 / 6 / 2012$ & $\mathrm{~m} 9$ & i-g-core & $1 b$ & 14161 & 2187 & 38336 & 4374 & 10285 & 936 & 10943 & 1419 & 6 & 2615 & 40 \\
\hline $2 / 6 / 2012$ & $\mathrm{~m} 1$ & i-g-core & $1 b$ & 17357 & 3307 & 21071 & 1897 & 7098 & 911 & 8858 & 1986 & 5 & 2616 & 36 \\
\hline $2 / 6 / 2012$ & $\mathrm{~m} 1$ & i-g-core & 1c & 727 & 94 & 53315 & 1836 & 8132 & 163 & 3093 & 512 & 5 & 2605 & 18 \\
\hline $6 / 20 / 2005$ & $\mathrm{~m} 9$ & i-g-core & $1 c$ & 1486 & 353 & 49890 & 3537 & 8028 & 686 & 3718 & 1092 & 16 & 2605 & 32 \\
\hline $2 / 6 / 2012$ & $\mathrm{~m} 18$ & i-g-rim & $1 \mathrm{c}$ & 471 & 37 & 107564 & 2966 & 13612 & 389 & 789 & 126 & 6 & 2596 & 18 \\
\hline $2 / 6 / 2012$ & $\mathrm{~m} 23$ & i-g-rim & $4 a$ & 28 & 24 & 14344 & 773 & 1350 & 61 & 224 & 40 & 4 & 1912 & 50 \\
\hline $2 / 6 / 2012$ & $\mathrm{~m} 24$ & m-gneiss & $4 a$ & 77 & 4 & 12008 & 273 & 1166 & 32 & 174 & 19 & 3 & 1976 & 98 \\
\hline $2 / 6 / 2012$ & $\mathrm{~m} 13$ & m-gneiss & $4 a$ & 54 & 38 & 10435 & 614 & 1022 & 60 & 264 & 35 & 9 & 1923 & 68 \\
\hline $2 / 6 / 2012$ & $\mathrm{~m} 21$ & i-g-rim & $4 a$ & 1096 & 49 & 20220 & 898 & 1872 & 74 & 248 & 51 & 6 & 1904 & 40 \\
\hline $6 / 20 / 2005$ & m22 & i-g-rim & $4 a$ & 58 & 4 & 3096 & 89 & 347 & 7 & 200 & 40 & 3 & 1940 & 130 \\
\hline \multicolumn{15}{|c|}{ Consistency standard Moacyr } \\
\hline $2 / 6 / 2012$ & - & - & - & 14040 & 93 & 61918 & 139 & 1480 & 11 & 912 & 35 & 5 & 508 & 9 \\
\hline $2 / 6 / 2012$ & - & - & - & 14268 & 87 & 61607 & 96 & 1469 & 20 & 885 & 12 & 5 & 507 & 13 \\
\hline $2 / 6 / 2012$ & - & - & - & 14383 & 110 & 62111 & 72 & 1468 & 17 & 850 & 22 & 5 & 504 & 12 \\
\hline $2 / 6 / 2012$ & - & - & - & 14490 & 174 & 62196 & 174 & 1459 & 18 & 843 & 26 & 5 & 500 & 10 \\
\hline $2 / 6 / 2012$ & - & - & - & 14439 & 209 & 62014 & 120 & 1477 & 11 & 833 & 39 & 5 & 508 & 6 \\
\hline $2 / 6 / 2012$ & - & - & - & 14505 & 94 & 61757 & 160 & 1471 & 10 & 853 & 5 & 5 & 508 & 8 \\
\hline $2 / 6 / 2012$ & - & - & - & 14675 & 145 & 61880 & 69 & 1473 & 3 & 840 & 39 & 5 & 508 & 4 \\
\hline \multicolumn{15}{|c|}{ Consistency standard GSC $8153^{\top}$} \\
\hline $6 / 20 / 2005$ & - & - & - & 4217 & 18 & 63937 & 87 & 1591 & 10 & 2405 & 30 & 7 & 494 & 6 \\
\hline $6 / 20 / 2005$ & - & - & - & 4173 & 23 & 63528 & 139 & 1582 & 12 & 2391 & 41 & 10 & 494 & 9 \\
\hline
\end{tabular}

*Setting Abbreviations: $\mathbf{i}=$ inclusion. $\mathbf{p} i=$ partial inclusion. $\mathrm{m}=$ matrix. $\mathrm{s} 1$ = type-1 sillimanite. $\mathrm{s} 2=$ type-2 sillimanite. $\mathrm{g}=$ garnet. lo-str = low strain domain. $\mathrm{myl}=$ mylonite.

Compositional domains were determined based on X-Ray maps of $\mathrm{U}, \mathrm{Th}, \mathrm{Y}, \mathrm{Ca}$, and $\mathrm{Si}$.

$\S$ Consistency standard Moacyr has the following ID-TIMS dates (Davis, W.J., pers. comm., 2007): $506.7 \pm 0.8 \mathrm{Ma}{ }^{207} \mathrm{~Pb} /{ }^{235} \mathrm{U}$, $515.2 \pm 0.6 \mathrm{Ma}{ }^{206} \mathrm{~Pb} /{ }^{238} \mathrm{U}, 506.4 \pm 1.0 \mathrm{Ma}{ }^{208} \mathrm{~Pb} /{ }^{232} \mathrm{Th}$.

† Consistency standard GSC 8153 has an ID-TIMS date of c. 500 Ma (Davis, W.J. \& Rayner, N., pers. comm., 2005). 
analyses were acquired for representative compositional domains and used to further characterize textural or compositional populations and for entry into the trace element analysis. Background intensities were evaluated and interference corrections were performed, following procedures in Jercinovic \& Williams (2005).

The method of calculating dates and errors follows Williams et al. (2006). For each homogeneous compositional domain at least 3 and typically 5 to 10 trace element analyses were obtained. Weighted mean compositions of $\mathrm{Th}, \mathrm{U}$, and $\mathrm{Pb}$ were calculated and used in the age equation of Montel et al. (1996) to calculate a single date for each domain. The $2 \sigma$ error reported here (Table 2) is two times the standard deviation. Data for each age domain are displayed graphically in the form of normal distribution curves (Fig. 14). Weighted means of dates from multiple domains of the same age population were calculated using the Isoplot/Ex v. 3 program of Ludwig (2003) with 95\% confidence errors. Data from the consistency standard for the two analytical sessions $(2005,2012)$ are also reported in Table 2. Standard GSC 8153 was dated at 500 Ma by ID-TIMS and SHRIMP (W.J. Davis \& N. Rayner, personal communication, 2005) and standard Moacyr was dated by ID-TIMS with weighted mean dates of $506 \pm 1.0 \mathrm{Ma}(2 \sigma, \mathrm{MSWD}=0.6)$ for $208 \mathrm{~Pb} / 232 \mathrm{Th}, 506.7 \pm 0.8 \mathrm{Ma}(2 \sigma, \mathrm{MSWD}=$ 0.83 ) for $207 \mathrm{~Pb} / 235 \mathrm{U}$, and $515.2 \pm 0.6 \mathrm{Ma}(2 \sigma, \mathrm{MSWD}=0.36)$ for $206 \mathrm{~Pb} / 238 \mathrm{U}$ (W.J. Davis, personal communication, 2007).

\section{Monazite occurrence, distribution, and composition}

Monazite grains occur in the matrix and as inclusions in garnet and sillimanite and show a range in morphologies. The grains range in size (long axis) from 10 to $100 \mu \mathrm{m}$. In several monazite grains from sample $03 \mathrm{M} 13$, compositional zoning is prevalent and observed within 
single monazite grains (Fig. 13a; populations 1a-1c). However, several grains that were analyzed are mostly homogeneous (Fig. 13b, c, e; populations 4a - 4b). Because Y content varies among some populations $(1 \mathrm{a}-1 \mathrm{c})$ and Th content varies among all populations, both $Y$ and Th concentrations are used to distinguish the populations. Therefore, using morphological and textural characteristics in addition to Th and $\mathrm{Y}$ concentrations, 5 populations were distinguished.

Monazite populations $1 \mathrm{a}-1 \mathrm{c}$ are exclusively present in sample $03 \mathrm{M} 13$ and primarily occur as inclusions in the relatively low-Ca core of garnet porphyroblasts (Fig. 4b). Population 1a generally contains the lowest Th concentrations (19000 - 20000 ppm, Table 2), moderate $Y$ concentrations ( 7000 ppm), and occurs as innermost cores (Fig. 13a). Population $1 \mathrm{~b}$ also occurs as inner cores, yet contains the highest $Y$ concentrations $(14000-18000 \mathrm{ppm})$ and relatively low Th concentrations (21000 - 38000 ppm). Population 1c contains high Th concentrations ( 50000 - $100000 \mathrm{ppm})$ and relatively low Y concentrations that variably range between 500 and 1500 ppm; this population occurs as mantles partially surrounding the higher Y, lower Th domains (1a and 1b; Fig. 13a).

Populations $4 \mathrm{a}$ and $4 \mathrm{~b}$ are generally similar in composition with characteristically low $\mathrm{Y}$ concentrations ( $<100-1000 \mathrm{ppm})$ and a wide range in Th concentrations (500 - $20000 \mathrm{ppm})$. These two populations generally lack a systematic variation in composition like that observed in the $1 \mathrm{a}-1 \mathrm{c}$ populations discussed above. However, two compositionally zoned monazite grains in sample 10W-098A (m31 and m3, Table 2; Fig. 13d) provide strong evidence for separate populations. These grains occur as an inclusion (Fig. 13f) and a partial inclusion in garnet and show complex compositional zoning, particularly in Th concentration. Based on 

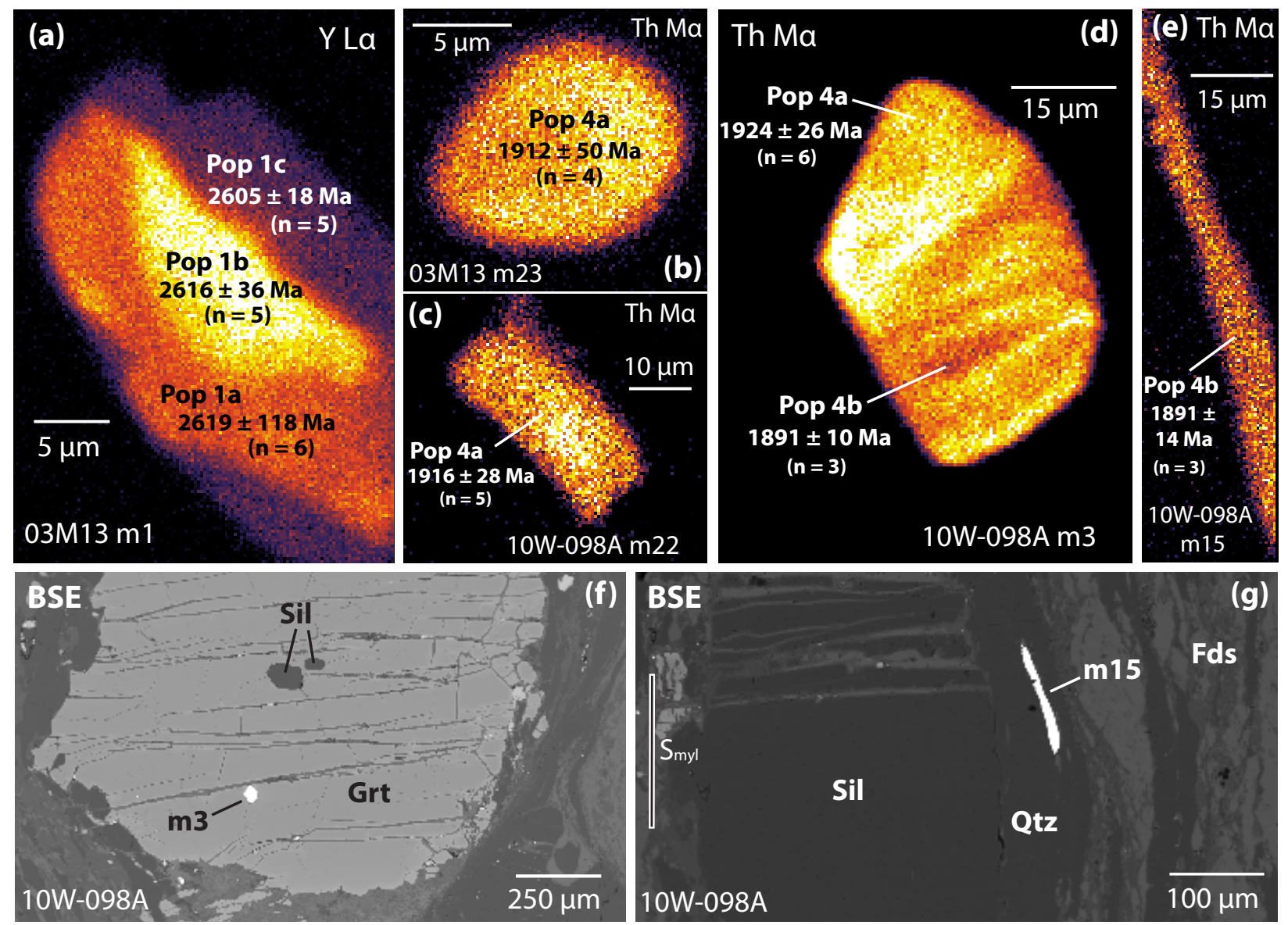

(g)

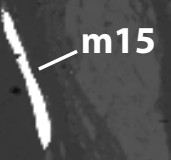

Fds

Sil

Qtz

$\overline{100 \mu \mathrm{m}}$

Fig. 13. Monazite from anhydrous felsic granulite $03 \mathrm{M} 13$ and 10W-098A. (a) Y La X-ray map of 03M13 m1. (b-e) Th Ma X-ray maps of 03M13 m23 and 10W-098A m22, m3, and m15, respectively. (f-g) BSE images showing textural settings of 10W-098A m3 and $\mathrm{m} 15$. Textural settings of $03 \mathrm{M} 13 \mathrm{~m} 1$ and $\mathrm{m} 23$ are shown in Fig. 4b. 
relatively sharp boundaries within the grains that define a change in Th concentration ( 40\%), two distinct domains are recognized: relatively high Th (27000; $87000 \mathrm{ppm})$ and relatively low Th (18000; $59000 \mathrm{ppm})$. Although the absolute Th concentrations are variable within each domain, the relative change in composition between the two domains within a single grain suggests two distinct populations of monazite growth.

Populations $4 \mathrm{a}$ and $4 \mathrm{~b}$ are differentiated on the basis of sample occurrence, morphology, and textural setting; both populations typically consist of homogeneous (non-zoned) grains (Fig. 13b, c, e). Notably, population 4a exclusively occurs in samples $03 \mathrm{M} 13$ and 10W-098A, whereas population $4 \mathrm{~b}$ only occurs in samples $10 \mathrm{~W}-098 \mathrm{~A}$ and $11 \mathrm{~L}-136 \mathrm{~B}$. Population $4 \mathrm{~b}$ grains have high average aspect ratios $(6: 1)$ with a shape-preferred orientation parallel to the stretching lineation (Fig. 13e); alternatively, grains of population 4a are equant in $03 \mathrm{M} 13$ and have much lower average aspect ratios ( $3: 1)$ than $4 \mathrm{~b}$ grains in 10W-098 A (Fig. 13b, c). Population 4a grains occur in $03 \mathrm{M} 13$ as inclusions in high-Ca rims of garnet (Fig. 4b) and in the protomylonitic matrix. Population 4a grains in 10W-098A occur in a variety of textural settings, including matrix and low strain (i.e., coarser-grained polyphase porphyroclast) domains and as a partial inclusion in type-2 sillimanite. Population $4 \mathrm{~b}$ grains also occur in several textural settings, including mylonitic ribbon matrix (Fig. 13g) and low strain (i.e., strain shadow, polyphase porphyroclast) domains and as inclusions in type-1 sillimanite.

\section{Geochronology results}

Results are listed in Table 2 and summarized in Fig. 14. The mean dates for populations 1a, $1 \mathrm{~b}$, and $1 \mathrm{c}$ are all indistinguishable within error and range between: $2637 \pm 25 \mathrm{Ma}$ for population 1a $(n=2) ; 2616 \pm 26$ Ma for $1 b(n=2)$; and, $2601 \pm 12$ Ma for 1c $(n=3$, weighted 


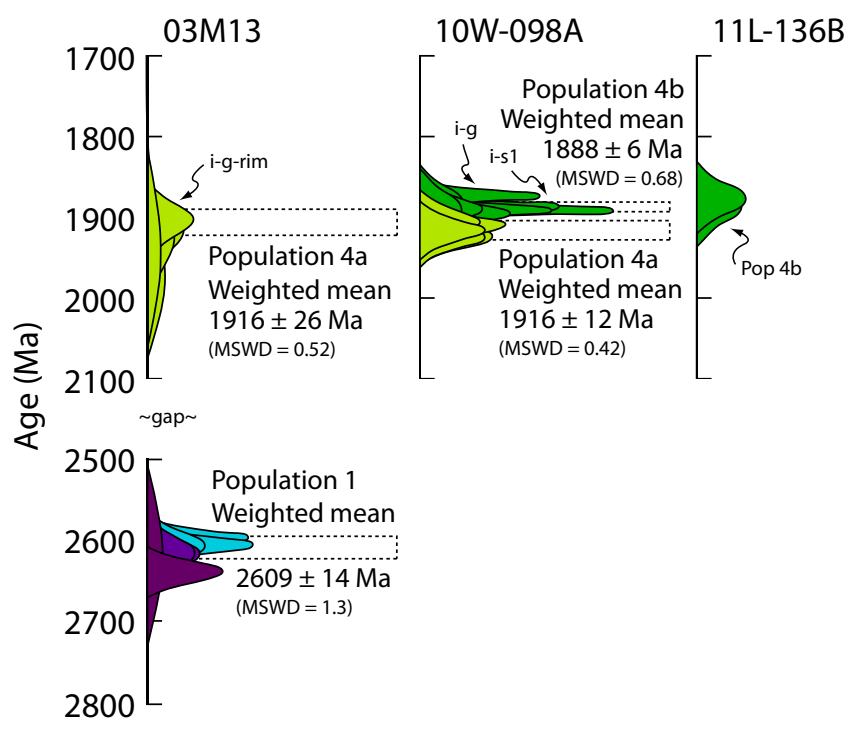

Fig. 14. Summary of electron microprobe monazite geochronology for three anhydrous felsic granulite samples. Each normal distribution curve represents the date and error for an individual compositional domain. The dashed rectangles bracket the $95 \%$ confidence intervals for the weighted mean dates. $\mathrm{i}-\mathrm{g}=$ inclusion in garnet. i-s1 = inclusion in type-1 sillimanite. 
mean, MSWD $=0.28$. All seven domains that comprise these populations are inclusions in garnet in sample $03 \mathrm{M} 13$ and together yield a weighted mean of $2609 \pm 14 \mathrm{Ma}(\mathrm{MSWD}=1.3$ ). We correlate these data with population 1 of Mahan et al. (2006b). These data indicate several distinct episodes of monazite growth at c. 2.61 Ga prior to or during garnet growth.

Population 4a dates range from $1904 \pm 40$ Ma to $1976 \pm 98$ Ma with weighted mean dates from samples 10W-098A and 03M13 of $1916 \pm 12 \mathrm{Ma}(n=5, M S W D=0.42)$ and $1916 \pm 26(n=$ $5, \mathrm{MSWD}=0.52)$, respectively. Population 4b dates range between $1873 \pm 16 \mathrm{Ma}$ and $1895 \pm$ $20 \mathrm{Ma}$ in samples 10W-098A and 11L-136B. A weighted mean date of $1888 \pm 6 \mathrm{Ma}$ (MSWD $=$ $0.68)$ is calculated from sample $10 \mathrm{~W}-098 \mathrm{~A}$ alone $(n=8)$ and a weighted mean date of $1887 \pm 6$ Ma $(M S W D=0.57)$ is calculated from ten domains in samples 10W-098A $(n=8)$ and 11L-136B $(\mathrm{n}=2)$. These data indicate two distinct episodes of monazite growth at c. $1.92 \mathrm{Ga}$ and c. 1.89 Ga, both of which most closely correspond with the second regional high-pressure granulite facies metamorphic event at $\sim 1.9 \mathrm{Ga}$. 


\section{DISCUSSION}

\section{Sillimanite deformation and recrystallization mechanisms}

Prior to this study, sillimanite deformation mechanisms in naturally deformed rocks were largely unconstrained. The disparate microstructures observed in sillimanite in anhydrous felsic granulite and hydrous felsic amphibolite can elucidate deformation and recrystallization mechanisms operating in sillimanite under contrasting conditions. In turn, the deformation mechanisms that were active in sillimanite can be directly correlated with the environmental conditions, including temperature, fluid-content, and strain magnitude, under which deformation occurred.

Based on results for anhydrous felsic granulite from the Cora Lake shear zone, important constraints can be placed on sillimanite deformation behavior at a relatively high magnitude of strain and under high-pressure granulite facies conditions, $1.0 \mathrm{GPa}, 800-900^{\circ} \mathrm{C}$ (Mahan et al., 2008). The presence of intracrystalline deformation and subgrain microstructure in addition to the large misorientation angles between subgrains, suggest that dislocation creep-accommodated subgrain rotation recrystallization is the dominant mechanism by which sillimanite deforms under anhydrous conditions in the lower crust, $\sim 35 \mathrm{~km}$ paleodepth. Additionally, the absence of hydrous fluid is inferred to have largely facilitated preservation of this dynamic microstructure. This is consistent with the high-temperature quartz [001] patterns and the matrix ultramylonitic fabric in samples 10W-098A and 11L-136B. Subgrain rotation recrystallization is also typically documented in other minerals (i.e., quartz, garnet) deformed under relatively high temperature conditions (e.g., Tullis, 2002; Martelat et al., 2012). 
Based on results for hydrous felsic amphibolite from the Grease River shear zone, important constraints can be placed on sillimanite behavior when deformed at 0.4-0.5 GPa under fluid-infiltrated retrograde conditions (Mahan et al., 2006b). Sillimanite in hydrous felsic amphibolite is characterized by bent or kinked porphyroclasts with foliation-parallel euhedral needles developed at the tails of and adjacent to serrated margins of porphyroclasts. Bent sillimanite porphyroclasts indicate minor dislocation glide activity. The spatial association of morphologically distinct sillimanite needles with sillimanite porphyroclasts, either as tails or adjacent to serrated margins, suggests that the parent alumino-silicate material dissolved and was reprecipitated in foliation-parallel tails or syntaxially adjacent to margins. Thus, dissolution-reprecipitation is the dominant mechanism by which sillimanite recrystallizes in a hydrated mid-crustal ( 20km paleodepth) shear zone. This may also have been accompanied by growth of new matrix sillimanite, which is consistent with petrological modeling that predicts production of sillimanite during retrograde metamorphism in similar felsic compositions (Mahan et al., 2006b).

\section{Sillimanite slip systems and nucleation orientations}

Only a few studies have performed quantitative analyses on deformation-induced crystallographic fabrics in sillimanite (i.e., Doukhan \& Christie, 1982; Doukhan et al., 1985; Lambregts \& van Roermund, 1990; Goergen et al., 2008). The more recent studies (Lambregts \& van Roermund, 1990; Goergen et al., 2008) agree on the importance of [001]-parallel slip in sillimanite; however, the slip systems that are reported vary: (010)[100] and (100)[010]

(Doukhan \& Christie, 1982; Doukhan et al., 1985); (100)[001] and minor (001)[100] (Lambregts \& van Roermund, 1990); and, (010)[001] (Goergen et al., 2008). 
One key result from this work is the prevalence of sillimanite [001] parallelism with the shear direction in all samples, despite differences in the mechanisms and/or conditions of deformation. This suggests that in sillimanite with intracrystalline deformation (i.e., 10W-098A and 03M166B type-1, 11L-136B), [001]-parallel slip was active. Conversely, in sillimanite with negligible intracrystalline deformation (10W-098A type-2, 03M166B type-3, 03M13, 04G029B), sillimanite may be nucleating and/or growing in a preferred orientation with [001] parallel to the shear direction; this is consistent with microstructural observations of elongate sillimanite prisms developing a shape-preferred orientation whereby the ([001]-parallel) longaxis of the crystal aligns parallel to the stretching lineation during deformation. Fast reaction kinetics parallel to [001] also supports preferential crystal growth along [001] (e.g., Cesare et al., 2002).

As established above, sillimanite in anhydrous felsic granulite samples 10W-098A (type-1) and 11L-136B deformed via dislocation creep-accommodated subgrain rotation recrystallization. The orientations of subgrain boundaries are controlled by the orientation of the slip system of the accumulated dislocations; the slip plane normal and slip direction should be perpendicular to the rotation axis (Trepied et al., 1980). Sillimanite subgrain boundaries from naturally deformed rocks were measured parallel to both (010) and (001) in a previous study by Lambregts \& van Roermund (1990). Thus, the interpretation followed that recrystallization is accommodated by rotation of subgrains around [010] by active slip on (100)[001] (Lambregts \& van Roermund, 1990). Based on EBSD results from this study, there may be a slight tendency for slip along (010), although slip may also occur along (100). This suggests that both (100) and (010) may be active with neither being dominant. With 
increasing strain, a progressive misorientation of a subgrain boundary leads to the eventual formation of a high-angle grain boundary and new (daughter) grains are developed. Based on this statement, the highly misoriented $\left(\leq 40^{\circ}\right)$ sillimanite "subgrain" boundaries within a single porphyroclast in sample 10W-098A requires a relatively high magnitude of strain. And, although the misorientation angles between grains are likely enhanced by fracturing, this affect is probably negligible given the relatively sparse occurrence of brittle microstructure. A high magnitude of strain is consistent with field and optical evidence for ultramylonitization along the Cora Lake shear zone.

Anhydrous felsic granulite sample 10W-098A also comprises essentially undeformed sillimanite. The crystallographic preferred orientation observed in type-2 sillimanite is interpreted to indicate nucleation in a preferred orientation relative to the strain field with [001] parallel to the shear direction and (010) parallel to the foliation plane. Sillimanite in sample $03 \mathrm{M} 13$ similarly only shows minor intracrystalline deformation, however, the crystallographic orientations are relatively random. A diffusion creep deformation mechanism may be inferred for crystals lacking a preferred crystallographic orientation (e.g., Passchier \& Trouw, 1996). However, because diffusion creep is grain-size sensitive and involves much finer-grained material (generally $<50 \mu$ m; e.g., Rutter \& Brodie, 1992) than sillimanite porphyroclasts in this study ( $\geq 150 \mu \mathrm{m}$ and up to $500 \mu \mathrm{m})$, this mechanism is not favored; additionally, microstructural evidence for diffusion creep, such as lobate grain boundaries, are lacking. Thus, sillimanite in sample 03M13 may have crystallized in a low strain regime without much regard to kinematic axes; this is consistent with the relatively low strain (protomylonitic) matrix fabric in this sample. Alternatively, the shape preferred orientation of 
type-2 sillimanite in samples 10W-098A and 03M13 may be indicative of mechanical rotation of the crystals into a preferential orientation relative to the strain field, or into a random orientation, respectively.

Sillimanite in hydrous felsic amphibolite is interpreted to have recrystallized via fluidassisted dissolution-reprecipitation. The crystallographic orientation of foliation-parallel euhedral sillimanite needles (03M166B type-3) suggests growth in a preferred orientation with [001] parallel to the shear direction and either (100) or (010) parallel to the foliation. In sample 04G-029B, the remarkably consistent [001] orientation parallel to the shear direction and the lack of a preferred orientation of (100) and (010) relative to the kinematic reference frame (i.e., the foliation plane) may be indicative of a strain field dominated by constriction $(\mathrm{L} \geq \mathrm{S})$.

\section{Implications: Rheology and strain localization}

The results of this study have important implications for the rheology and strain localization in aluminous felsic tectonites from the microscopic to regional scale. The rheology of a given rock depends primarily on the physical conditions of deformation (i.e., temperature, fluid-content, pressure), the relative proportions and distribution of weak and strong minerals, and grain size (Handy, 1990; Rutter \& Brodie, 1992).

First, the prominent role of fluid in sillimanite deformation is demonstrated on a regional scale. One key result of this study is that sillimanite behaves much differently in the presence of a fluid (and at lower temperature and pressure) in mid-crustal retrograde tectonite than sillimanite in lower-crustal granulite facies tectonite: the fluid induces dissolution and reprecipitation of sillimanite, whereas anhydrous sillimanite deforms by dislocation creep 
processes. Nucleation and growth of minerals (i.e., sillimanite) during metamorphism may result in strength hardening since the new grains are essentially dislocation-free and thus, the critical shear stress (and stored energy) is reset (e.g., Wenk \& Tome, 1999). Further, because the same hydrous retrograde metamorphic reactions commonly produce significantly weaker hydrous phases, (i.e., micas; Tullis, 2002), these phases will accommodate the bulk of the strain and sillimanite will be essentially undeformed in amphibolite-facies tectonites.

Strain localization at the microscopic scale within felsic granulite sample 10W-098A is manifested by the presence of sillimanite with extensive intracrystalline deformation (type-1) and essentially undeformed sillimanite (type-2). This effect may be influenced by the distribution and composition of interconnected weak layers in addition to grain size. First, strain accommodation is likely influenced by the rheology of surrounding phases: the greater the strength contrast between weak and strong phases, the more the weak phase will accommodate strain (e.g., Handy, 1990). For instance, type-2 sillimanite occurs as isolated grains in quartzofeldspathic matrix layers; thus, the much weaker quartz and feldspar may have accommodated the bulk of the strain and the sillimanite remained essentially undeformed. Conversely, type-1 sillimanite primarily occurs in sillimanite- and garnet-rich layers; thus, because there is more sillimanite than garnet in these layers and sillimanite is the weaker phase in those layers, it might have accommodated the bulk of the strain and more readily deformed.

Strain localization may also be influenced by different grain sizes, given that finer-grained materials are generally slightly stronger than their coarser equivalents based on the inverse relationship between grain size and strain rate for power-law creep (e.g., Rutter \& Brodie, 
1992). In turn, grain size reduction via dynamic recrystallization enhances the ductility of the weak phase with respect to the strong phase which allows the weak phase to accommodate more strain (Handy, 1990). Therefore, it is quite possible that type-1 sillimanite grains ( $\leq 3 \mathrm{~mm}$ ) accommodated more strain due to their larger grain size than type-2 grains ( 500 $\mu \mathrm{m})$. Accordingly, as subgrain rotation recrystallization proceeded and ductility was enhanced in type-1 sillimanite, it was weakened and continued to deform. Interestingly, the strong crystallographic preferred orientation of type-2 sillimanite relative to the strain field implies an easy-slip orientation where weakening and intracrystalline deformation might localize (e.g., Rutter \& Brodie, 1992). However, this may be reconciled assuming that nucleation of a new grain (type-2 sillimanite), even if in an "easy" orientation, may deform less readily than grains in a hard orientation (type-1 sillimanite) because they are dislocation-free and their critical shear stress has been reset (e.g., Wenk \& Tome, 1999).

It has also been demonstrated that once a shear zone has been nucleated, it is easier for deformation to continue within it than to spread throughout the rock volume (i.e., straindependent weakening mechanism; Rutter \& Brodie, 1992; Holyoke \& Tullis, 2006). This may explain the intense and efficient localization of strain along the Cora Lake shear zone, where felsic granulite ultramylonite just west of Cora Lake is separated by essentially undeformed felsic granulite at Beech Lake by $\leq 5 \mathrm{~km}$.

\section{Implications: Seismic anisotropy}

Because [001] corresponds to the direction of maximum P-wave velocity in sillimanite, a preferred orientation of sillimanite [001] causes a more pronounced seismic anisotropy (Weiss et al., 1999). Sillimanite from all samples in this study shows a strong [001] alignment parallel 
to the stretching lineation, which has significant implications for the anisotropy of sillimanitebearing granulite- and amphibolite-facies shear zones.

In sillimanite-bearing felsic tectonites from the Cora Lake shear zone, where other anisotropic minerals (i.e., micas) may be absent, P-waves might be expected to travel fastest parallel to sillimanite [001] (i.e., the stretching lineation). Thus, seismically imaged anisotropic lower-crustal shear zones (i.e., Tibetan Plateau, Sherrington et al., 2004), may be significantly influenced by sillimanite [001] alignment, especially if similar in composition to the Cora Lake shear zone. In turn, seismically imaged lower-crustal shear zones (i.e., Main Himalayan Thrust, Schulte-Pelkum et al., 2005; Mahan, 2006) that are isotropic may be a result of a different shear zone composition (i.e., sillimanite-absent) than that studied here.

In amphibolite-facies tectonites, the directional dependence of seismic velocities is controlled by the volume content and fabric strength of mica and sillimanite (Weiss et al., 1999). Therefore, in amphibolite-facies shear zones like the Grease River shear zone, where both biotite and sillimanite are abundant and preferentially oriented relative to the strain field, a constructive interference of the fast axis of sillimanite (i.e., [001]) and the fast plane of biotite (i.e., (001)) will create a highly anisotropic shear zone (Weiss et al., 1999).

\section{Timing constraints}

The $2.61 \mathrm{Ga}$ monazite dates most closely associated with garnet growth in sample 03M13 correspond with the syntectonic emplacement of granitic protoliths in the northwestern domain (Williams et al., 2000). It should also be noted that none of the samples in this study show evidence for monazite growth during the regional c. $2.55 \mathrm{Ga}$ high-pressure granulite facies metamorphic event; perhaps monazite growth was restricted to $2.61 \mathrm{Ga}$ and was later 
encapsulated by 2.55 Ga garnet, similar to the interpretation of Baldwin et al. (2006) that growth of older (i.e., c. $2.62 \mathrm{Ga}$ ) monazite was armored in c. 2.55 Ga garnet in felsic granulite from the southern domain.

Later episodes of monazite growth documented in samples from this study are at $1.92 \mathrm{Ga}$ and c. $1.89 \mathrm{Ga}$. Both of these dates most closely correspond with the second regional highpressure granulite facies metamorphic event at $\sim 1.9 \mathrm{Ga}$. However, with these new data, the date of this regional metamorphic event can be more precisely determined. The $1.92 \mathrm{Ga}$ date is most closely associated with high-Ca garnet growth and the protomylonitic fabric in 03M13; these textural relationships suggest deformation under lower temperature or higher pressure conditions and a lower magnitude of strain at $1.92 \mathrm{Ga}$. Prior work has also revealed evidence for a period of monazite growth in felsic granulites around this time $(\sim 1.92 \mathrm{Ga})$. In retrograde felsic granulite sample 03M166B, monazite dates in population 4 yielded a weighted mean of $1915 \pm 23$ Ma (Mahan et al., 2006b). Further, a population of monazite dates from another retrograde felsic granulite sample (02M194B) in the eastern Chipman domain yielded a weighted mean of $1929 \pm 32$ Ma (Mahan et al., 2006a). Importantly, a monazite inclusion in sillimanite in sample 03M166B yielded a date of $1937 \pm 27$ Ma (Mahan et al., 2006b). Additionally, high-precision U-Pb ID-TIMS analyses on zircon fragments from a deformed migmatitic dike (sample 03-52) in the central Chipman domain yielded dates in this range (i.e., 1920 and $1922 \mathrm{Ma}$ ) that were $0.3-0.4 \%$ discordant (Flowers et al., 2006a). Synkinematic growth of 1.92 to 1.90 Ga monazite under lower-crustal conditions has also been documented along the Grease River shear zone (Dumond et al., 2008). 
The 1.89 Ga date is most closely associated with: garnet and sillimanite growth, hightemperature deformation (as documented in type-1 sillimanite), and mylonitic fabric development in samples along the sinistral strike-slip Cora Lake shear zone (10W-098A, 11L136B). Importantly, a 1.89 Ga monazite inclusion in sample 10W-098A provides a maximum age of growth and intracrystalline deformation of type-1 sillimanite. Therefore, the second episode of regional high-pressure granulite facies metamorphism may be more tightly constrained to $1.89 \mathrm{Ga}$. High-temperature metamorphism at this time is supported by 1.896 Ga dike anatexis and $1.889 \mathrm{Ga}$ (mean titanite $\mathrm{U}-\mathrm{Pb}$ date) decompression following dike anatexis (Flowers et al., 2006a; 2006b).

\section{Tectonometamorphic evolution of felsic tectonite in the East Athabasca mylonite triangle}

The textural setting (i.e., included in garnet cores) and high $\mathrm{Y}$ concentration of population 1 monazite $(2.61 \mathrm{Ga})$ suggest that this monazite grew before or during garnet growth. Therefore, we interpret the initial anhydrous assemblage (Grt + Sil + PI + Kfs + Qtz \pm Rt) in felsic granulite at Beech Lake to have formed during late Archean granulite facies metamorphism (Fig. 15). This is similar to the provenance suggested for felsic granulite in the southern domain (Baldwin et al., 2006) and the Chipman domain (Mahan et al., 2006b); it is also consistent with syntectonic emplacement of the granitoid gneiss during granulite facies metamorphism at this time (Williams et al., 2000). Archean-age monazite is not present in felsic granulite at Cora Lake and Goodie Ring Lake, suggesting a complete reworking of older textures, including monazite, during the $1.89 \mathrm{Ga}$ tectonometamorphic event.

The results of this study elucidate a distinct episode of deformation at $1.92 \mathrm{Ga}$ in the Beech Lake area (Fig. 15). The textural settings (i.e., inclusions in high-Ca garnet and in matrix 


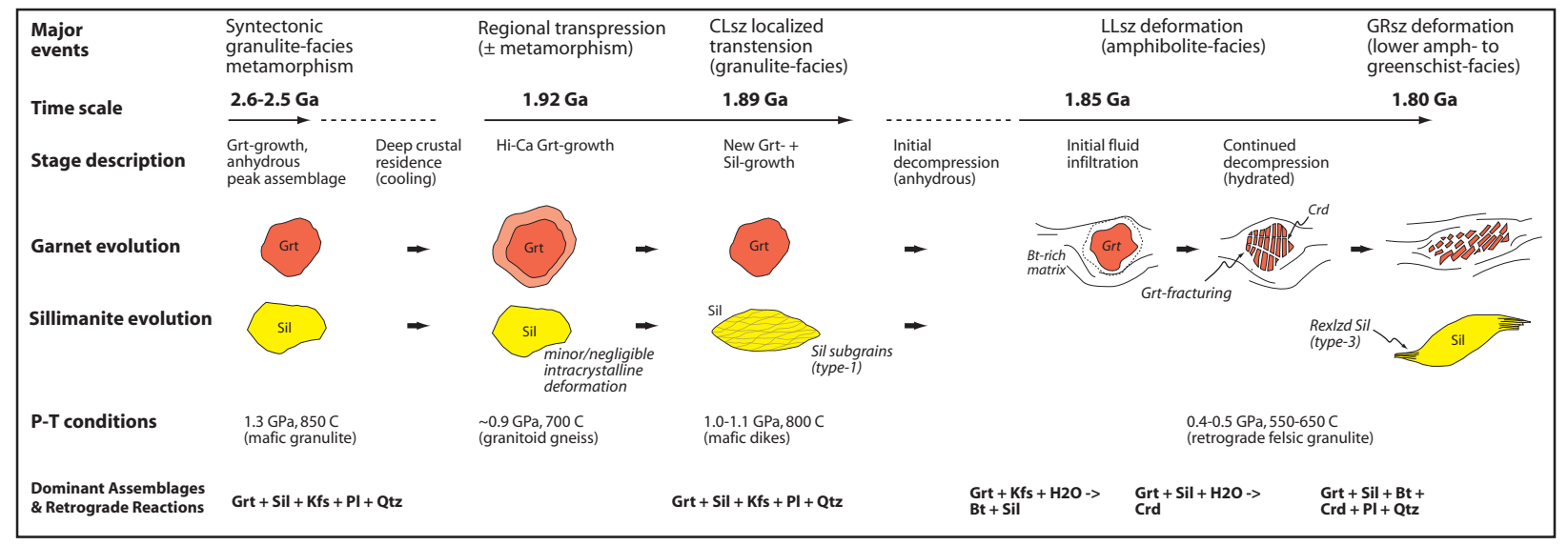

Fig. 15. Summary model for evolution of felsic tectonites (modified after Mahan et al., 2006b). CLsz = Cora Lake shear zone, LLsz = Legs Lake shear zone, GRsz = Grease River shear zone. 
domains) of population 4a monazite $(1.92 \mathrm{Ga})$ suggest that it grew before or coeval with growth of high-Ca garnet and protomylonitic deformation of the matrix. Increased Ca in garnet rims and in matrix garnet may reflect decreased temperature, increased pressure, or a change in the effective bulk composition. However, based on thermobarometric estimates for the northwestern domain at this time (i.e., $\sim 0.9 \mathrm{GPa}, 700^{\circ} \mathrm{C}$; Dumond et al., 2008; Regan et al., 2012; Fig. 2), an increase in pressure (since Archean garnet growth) is not likely. Moreover, the lack of sillimanite subgrain microstructure may lend support of lower temperature $\left(\leq 800{ }^{\circ} \mathrm{C}\right)$ deformation. Thus, the lack of sillimanite subgrain microstructure and crystallographic preferred orientation, growth of high-Ca garnet, and low-strain protomylonitic matrix fabric development in sample $03 \mathrm{M} 13$ suggest that deformation and metamorphism occurred at $\sim 700^{\circ} \mathrm{C}, \sim 0.9 \mathrm{GPa}$ (Fig. 2) and low strain at $1.92 \mathrm{Ga}$ (Fig. 15). This is consistent with high-Ca garnet growth at $\sim 1.9$ Ga proposed for felsic granulite in the southern domain (Baldwin et al., 2006) and in the Chipman domain (Mahan et al., 2006b). Further, as discussed above, this approximate date is recorded in samples from other regions in the East Athabasca mylonite triangle, including the Cora Lake shear zone (i.e., sample 10W-098A), the Grease River shear zone, and several areas in the Chipman and northwestern domains. Therefore, this appears to be a pervasive event in the East Athabasca mylonite triangle. Because kinematic indicators are dominantly dextral in this region (northwest of Beech Lake) and dextral transpression is prevalent along the Grease River shear zone at this time (Dumond et al., 2008), this $1.92 \mathrm{Ga}$ event is correlated with dextral transpression at Beech Lake. Further, we may correlate this $1.92 \mathrm{Ga}$ tectonism with contraction documented to the north in the Snowbird Lake area (Martel et al., 2008; Fig. 1a). Regional compression at this time may reflect a late stage of the 
Taltson orogeny (e.g., McDonough et al., 2000) or an early stage of the Trans-Hudson orogeny (e.g., Hoffman, 1988).

The textural settings (i.e., inclusions in garnet and type-1 sillimanite) of population $4 \mathrm{~b}$ monazite $(1.89 \mathrm{Ga})$ in sample 10W-098A constrain garnet and sillimanite growth and sillimanite subgrain microstructure development to $1.89 \mathrm{Ga}$. This is supported by the characteristically high aspect ratio and lineation-parallel shape preferred orientation of population $4 \mathrm{~b}$ monazite in the ultramylonitic matrix, suggesting that high strain deformation occurred at $1.89 \mathrm{Ga}$. Kinematic indicators (i.e., field observations and quartz [001] asymmetry) for deformation along the Cora Lake shear zone (CLsz) record sinistral shear with a minor component of extension (NW side down). Therefore, CLsz sinistral-normal oblique shear and coupled granulite facies metamorphism is now constrained to $1.89 \mathrm{Ga}$, only 30 m.y. subsequent to dextral shear recorded at Beech Lake $\leq 5 \mathrm{~km}$ away (Fig. 15). Paleoproterozoic high temperature deformation is also documented along the northern extension of the CLsz. This is supported by: (1) population 4b monazite (1.89 Ga) with a shape-preferred orientation parallel to the stretching lineation in the ultramylonitic matrix in sample $11 \mathrm{~L}-136 \mathrm{~B}$, which also comprises type-1 sillimanite (Goodie Ring Lake; Fig. 3); and, (2) growth and intracrystalline deformation of sillimanite at or after $1937 \pm 27$ Ma (monazite inclusion in type- 1 sillimanite in sample 03M166B; Fig. 1c; Mahan et al., 2006b).

The prevalence of population $4 a(1.92 \mathrm{Ga})$ monazite, the lack of population $4 \mathrm{~b}(1.89 \mathrm{Ga})$ monazite, and the lack of intracrystalline deformation in sillimanite in sample $03 \mathrm{M} 13$ suggests that the 1.92 Ga event may not have produced intracrystalline deformation in sillimanite and that sample $03 \mathrm{M} 13$ was not affected by the $1.89 \mathrm{Ga}$ event. Of course, the lack of population 
$4 \mathrm{~b}$ monazite in sample $03 \mathrm{M} 13$ doesn't necessarily prove that this sample was not affected by deformation at $1.89 \mathrm{Ga}$; however, given the $1.89 \mathrm{Ga}$ ultramylonitic fabric and pervasive intracrystalline deformation development in type-1 sillimanite in sample 10W-098A, we might expect a stronger mylonitic fabric and/or intracrystalline deformation in sillimanite in sample $03 \mathrm{M} 13$ if it was affected by this event. It cannot be absolutely ruled out that strain localization at 1.89 Ga may account for the lack of intracrystalline deformation in sillimanite in sample 03M13, where the large ( $>8 \mathrm{~mm}$ diameter) garnet porphyroclasts and/or the high proportion of garnet in matrix layers with sillimanite may have "shielded" the sillimanite from deformation. However, given several factors together, including the lack of population $4 \mathrm{~b}$ monazite, low-strain protomylonitic matrix fabric, and essentially undeformed sillimanite, I favor the interpretation that sample $03 \mathrm{M} 13$ did not experience the $1.89 \mathrm{Ga}$ event.

CLsz transtension and granulite facies metamorphism at $1.89 \mathrm{Ga}$ post-dates partial melting of Chipman mafic dikes at $1.896 \mathrm{Ga}$. This can be interpreted to reflect granulite facies metamorphism as a result of the heat produced during regional extension and dike anatexis. This is consistent with a protracted $\left(\sim 14\right.$ m.y.) metamorphic event at $\mathrm{T} \geq 600-650^{\circ} \mathrm{C}$ subsequent to $1.896 \mathrm{Ga}$ dike anatexis (Flowers et al., 2006b). In addition, because $1.89 \mathrm{Ga}$ tectonometamorphism is not recorded at Beech Lake, this constrains the northwestern boundary of $1.89 \mathrm{Ga}$ CLsz deformation to the $\sim 5 \mathrm{~km}$ between the western side of Cora Lake and the southeastern side of Beech Lake (Fig. 3).

Localized retrograde metamorphism along exhumation-related shear zones initiated $\sim 40$ m.y. subsequent to granulite-facies metamorphism along the CLsz. These events may be correlated with the beginning stages of the Trans-Hudson orogeny to the southeast (Fig. 1a; 
e.g., Hoffman, 1988; Mahan \& Williams, 2005; Mahan et al., 2006b). Decompression and fluid infiltration under amphibolite-facies conditions along the Legs Lake shear zone beginning at $1.85 \mathrm{Ga}$ induced retrogression of the granulite facies assemblage and the production of biotite and sillimanite (Mahan et al., 2006b). The results of this study demonstrate that continued synkinematic hydration during dextral shear along the Grease River shear zone at 1.80 Ga played a fundamental role in triggering dissolution of the "protolith" sillimanite and reprecipitation of morphologically distinct retrograde sillimanite. 


\section{CONCLUSIONS}

Prior to this study, sillimanite deformation behavior in naturally deformed rocks was largely unconstrained. One important conclusion from this work is that the presence of a fluid plays a significant role in sillimanite deformation and recrystallization. Results here indicate that dislocation creep-accommodated subgrain-rotation on both (100)[001] and (010)[001] is the dominant dynamic recrystallization mechanism operating in sillimanite under high strain, granulite-facies conditions in the CLsz. In contrast, dissolution-reprecipitation is the major dynamic recrystallization mechanism in sillimanite under fluid-infiltrated retrograde conditions in the GRsz, where synkinematic growth of foliation-parallel euhedral sillimanite is in a preferred orientation with [001] parallel to the shear direction and either (100) or (010) parallel to the foliation. This study also demonstrates that intracrystalline deformation does not occur in sillimanite where strain is apparently localized in surrounding weaker phases. Sillimanite nucleation orientation appears to be dependent on strain magnitude: at highstrain along the CLsz, sillimanite nucleates in a preferred orientation relative to the strain field with [001] parallel to the shear direction and (010) parallel to the foliation plane; in contrast, sillimanite nucleation orientations appear to be relatively random in low-strain regimes. Importantly, sillimanite [001] alignment parallel to the stretching lineation is apparent in all samples of this study regardless of contrasts in conditions and/or mechanisms of deformation, which has significant implications for deep crustal anisotropy.

Monazite records two distinct Paleoproterozoic tectonometamorphic events separated by 30 million years and thus, helps to deconvolve a complicated regional tectonic history. Synkinematic metamorphism under relatively low-strain and lower temperature $\left(\leq 800^{\circ} \mathrm{C}\right)$ 
conditions at $1.92 \mathrm{Ga}$ is interpreted to correspond with regional dextral transpression.

Localized synkinematic granulite-facies metamorphism and high-strain deformation at 1.89

Ga is associated with sinistral transtension along the Cora Lake shear zone. With an increased understanding of the evolution of rheological and seismic properties through the crustal column, important constraints can be placed on seismic interpretations, thus bridging the gap between exhumed exposures and modern lower crustal processes. 


\section{REFERENCES}

Anovitz, L.M., Essene, E.J., Metz, G.W., Bohlen, S.R., Westrum Jr., E.F., and Hemingway, B.S., 1993. Heat capacity and phase equilibria of almandine, Fe3Al2Si3012. Geochimica et Cosmochimica Acta, 57, 4191-4204.

Baldwin, J.A., Bowring, S.A. \& Williams, M.L., 2003. Petrologic and geochronologic constraints on high-pressure, high temperature metamorphism in the Snowbird tectonic zone, Canada. Journal of Metamorphic Geology, 21, 81-98.

Baldwin, J.A., Bowring, S.A., Williams, M.L. \& Williams, I. S., 2004. Eclogites of the Snowbird tectonic zone: petrological and U-Pb geochronological evidence for Paleoproterozoic highpressure metamorphism in the western Canadian Shield. Contributions to Mineralogy and Petrology, 147, 528-548.

Baldwin, J.A., Bowring, S.A., Williams, M.L. \& Mahan, K.H., 2006. Geochronological constraints on the crustal evolution of felsic high-Pressure granulites, Snowbird tectonic zone, Canada. Lithos, 88, 173-200.

Baldwin, J.A., Powell, R., Williams, M.L. \& Goncalves, P., 2007. Formation of eclogite, and reaction during exhumation to mid-crustal levels, Snowbird tectonic zone, western Canadian Shield. Journal of Metamorphic Geology, 25, 953-974.

Cesare, B., Gomez-Pugnaire, M.T., Sanchez-Navas, A. \& Grobety, B., 2002. Andalusite-sillimanite replacement (Mazarron, SE Spain): A microstructural and TEM study. American Mineralogist, 87, 433-444.

Doukhan, J. \& Christie, J.M., 1982. Plastic deformation of sillimanite $\mathrm{Al}_{2} \mathrm{SiO}_{5}$ single crystals under confining pressure and TEM investigation of the induced defect structure. Bulletin of Mineralogy, 105, 583-589.

Doukhan, J., Doukhan, N., Koch, P.S., \& Christie, J.M., 1985. Transmission electron microscopy investigation of lattice defects in $\mathrm{Al}_{2} \mathrm{SiO}_{5}$ polymorphs and plasticity induced polymorphic transformations. Bulletin of Mineralogy, 108, 81-96.

Dumond, G., Goncalves, P., Williams, M.L., and M.J. Jercinovic, 2010. Sub-horizontal fabric in exhumed continental lower crust and implications for lower crustal flow: Athabasca granulite terrane, western Canadian Shield. Tectonics, vol. 29, TC2006, doi:10.1029/2009TC002514.

Dumond, G., McClean, N., Williams, M.L. \& Jercinovic, M.J., 2008. High-resolution dating of granite petrogenesis and deformation in a lower crustal shear zone: Athabasca granulite terrane, western Canadian Shield. Chemical Geology. 
Etheridge, M.A., Wall, V.J., \& Cox, S.F., 1983. High fluid pressures during regional metamorphism and deformation: Implications for mass transport and deformation mechanisms. Journal of Geophysical Research, 89, 4344-4358.

Flowers, R.M., Bowring, S.A. \& Williams, M.L., 2006a. Timescales and significance of highpressure, high-temperature metamorphism and mafic dike anatexis, Snowbird tectonic zone, Canada. Contributions to Mineralogy and Petrology, 151, 558-581.

Flowers, R.M., Mahan, K.H., Bowring, S.A., Williams, M.L., Pringle, M.S. \& Hodges, K.V., 2006b. Multistage exhumation and juxtaposition of lower continental crust in the western Canadian Shield: Linking high-resolution U-Pb and 40Ar/39Ar thermochronometry with pressure-temperature-deformation paths. Tectonics, 25, TC4003.

Flowers, R.M., Bowring, S.A., Mahan, K.H., Williams, M.L., \& Williams, I.S., 2008. Stabilization and reactivation of cratonic lithosphere from the lower crustal record in the western Canadian shield. Contributions to Mineralogy and Petrology, doi: 10.1007/s00410-008-0301-5.

Fuhrman, M.L. \& Lindsley, D.H., 1988. Ternary-feldspar modeling and thermometry. American mineralogist, $73,201-215$.

Goergen, E.T., Whitney, D.L., Zimmerman, M.E., \& Hiraga, T., 2008. Deformation-induced polymorphic transformation: experimental deformation of kyanite, andalusite, and sillimanite. Tectonophysics, 454, 23-25.

Halfpenny, A., Prior, D.J., \& Wheeler, J., 2006. Analysis of dynamic recrystallization and nucleation in a quartzite mylonite. Tectonophysics, 427, 3-14.

Handy, M.R., 1990. The solid-state flow of polymineralic rocks. Journal of Geophysical Research, 95, 8647-8661.

Hanmer, S., 1994. Geology of the East Athabasca Mylonite Triangle, Map 1859A, 1:100,000. Geological Survey of Canada, Ottawa.

Hanmer, S., 1997. Geology of the Striding-Athabasca mylonite zone, northern Saskatchewan and southeastern District of Mackenzie, Northwest Territories, Bulletin 501. Geological Survey of Canada, Ottawa, 92.

Hanmer, S., Parrish, R., Williams, M.L. \& Kopf, C., 1994. Striding-Athabasca mylonite zone: Complex Archean deep-crustal deformation in the East Athabasca mylonite triangle, northern Saskatchewan. Canadian Journal of Earth Sciences, 31, 1287-1300.

Hanmer, S., Williams, M.L. \& Kopf, C., 1995a. Striding-Athabasca mylonite zone: Implications for the Archean and Early Proterozoic tectonics of the western Canadian Shield. Canadian Journal of Earth Sciences, 32, 178-196. 
Hanmer, S., Williams, M.L. \& Kopf, C., 1995b. Modest movements, spectacular fabrics in an intracontinental deep-crustal strike-slip fault: Striding-Athabasca mylonite zone, NW Canadian Shield. Journal of Structural Geology, 17, 493-507.

Harlov, D.E. \& Milke, R., 2002. Stability of corundum + quartz relative to kyanite and sillimanite at high temperature and pressure. American Mineralogist, 87, 424-432.

Holyoke, C.W. \& Tullis, J., 2006. Mechanisms of weak phase interconnection and the effects of phase strength contrast on fabric development. Journal of Structural Geology, 28, 621-640.

Hoffman, P.F., 1988. United Plates of America, the birth of a craton: Early Proterozoic assembly and growth of Laurentia. Annual Review of Earth and Planetary Sciences, 16, 543-603.

Jercinovic, M.J. \& Williams, M.L., 2005. Analytical perils (and progress) in electron microprobe trace element analysis applied to geochronology: background acquisition, interferences, and beam irrradiation effects. American Mineralogist, 90, 526-546.

Ji, S., Salisbury, M.H., \& Hanmer, S., 1993. Petrofabric, P-wave anisotropy and seismic reflectivity of high-grade tectonites. Tectonophysics, 222, 195-226.

Kerrick, D.M., 1990. The Al2SiO5 polymorphs, vol. 22, 406 p. Reviews in mineralogy, Mineralogical Society of America, Washington, D.C.

Kopf, C., 1999. Deformation, Metamorphism, and Magmatism in the East Athabasca Mylonite Triangle, Northern Saskatchewan: Implications for the Archean and Early Proterozoic Crustal Structure of the Canadian Shield. PhD Dissertation, University of Massachusetts-Amherst, Amherst, MA.

Lambregts, P.J., \& van Roermund, H.L.M., 1990. Deformation and recrystallization mechanisms in naturally deformed sillimanites. Tectonophysics, 179, 371-378.

Ludwig, K. R., 2003. Isoplot/Ex Version 3.00: A Geochronological Toolkit for Microsoft Excel. Berkeley Geochronology Center, Berkeley, CA.

Mahan, K., 2006. Retrograde mica in deep crustal granulites: Implications for crustal seismic anisotropy. Geophysical Research Letters, 33, L24301.

Mahan, K.H. \& Williams, M.L., 2005. Reconstruction of a large deep crustal exposure: Implications for the Snowbird Tectonic Zone and early growth of Laurentia. Geology, 33, 385-388. 
Mahan, K.H., Williams, M.L. \& Baldwin, J.A., 2003. Contractional uplift of deep crustal rocks along the Legs Lake shear zone, western Churchill Province, Canadian Shield. Canadian Journal of Earth Sciences, 40, 1085-1110.

Mahan, K.H., Smit, C.A., Williams, M.L., Dumond, G. \& van Reenen, D.D., 2011. Heterogeneous strain and polymetamorphism in high-grade terranes: Insight into crustal processes from the Athabasca Granulite Terrane, western Canada, and the Limpopo Complex, southern Africa, in van Reenen, D.D., Kramers, J.D., McCourt, S., \& Perchuk, L.L., eds., Origin and Evolution of Precambrian High-Grade Gneiss Terranes, with Special Emphasis on the Limpopo Complex of Southern Africa: Geological Society of America Memoir 207, 269-287.

Mahan, K., Williams, M., Flowers, R., Jercinovic, M., Baldwin, J. \& Bowring, S., $2006 a$. Geochronological constraints on the Legs Lake shear zone with implications for regional exhumation of lower continental crust, western Churchill Province, Canadian Shield. Contributions to Mineralogy and Petrology, 152, 1-20.

Mahan, K.H., Goncalves, P., Williams, M.L. \& Jercinovic, M.J., 2006b. Dating metamorphic reactions and fluid flow: application to exhumation of high-P granulites in a crustalscale shear zone, western Canadian Shield. Journal of Metamorphic Geology, 24, 193-217.

Mahan, K.H., Goncalves, P., Flowers, R.M., Williams, M.L., \& Hoffman-Setka, D., 2008. The role of heterogeneous strain in the development and preservation of a polymetamorphic record in high-P granulites, western Canadian Shield. Journal of Metamorphic Geology, 26, 669-694.

Marsh, J.H., Gerbi, C.C., Culshaw, N.G., Potter, J., Longstaffe, F.J., \& Johnson, S.E., 2011. Initiation and development of the Twelve Mile Bay shear zone: the low viscosity sole of a granite nappe. Journal of Metamorphic Geology, 29, 167-191.

Martel, E., van Breemen, O., Berman, R.G., \& Pehrsson, S., 2008. Geochronology and tectonometamorphic history of the Snowbird Lake area, Northwest Territories, Canada: new insights into the architecture and significance of the Snowbird tectonic zone. Precambrian Research, 161, 201-230.

Martelat, J.E., Malamoud, K., Cordier, P., Randrianasolo, B., Schulmann, K., \& Lardeaux, J.M., 2012. Garnet crystal plasticity in the continental crust, new example from south Madagascar. Journal of Metamorphic Geology, 30, 435-452.

McDonough, M.R., McNicoll, V.J., Schetselaar, E.M., \& Grover, T.W., 2000. Geochronological and kinematic constraints on crustal shortening and escape in a two-sided oblique-slip collisional and magmatic orogen, Paleoproterozoic Taltson magmatic zone, northeastern Alberta. Canadian Journal of Earth Sciences, 37, 1549-1573.

Montel, J.M., Foret, S., Veschambre, M., Nicollet, C. \& Provost, A., 1996. Electron microprobe dating of monazite. Chemical Geology, 131, 37-53. 
Musumeci, G., 2002. Sillimanite-bearing shear zones in syntectonic leucogranite: fluid-assisted brittle-ductile deformation under amphibolite facies conditions. Journal of Structural Geology, 24, 1491-1505.

Passchier, C.W. \& Trouw, R.A.J., 1996. Microtectonics. Springer, Berlin, 289 p.

Regan, S., Williams, M.L., Holland, M.E., Leslie, S., Mahan, K.H., Jercinovic, M.J., \& Allaz, J., 2012. Interpreting the tectonic history of crustal-scale high strain zones: Insights from the Cora Lake shear zone, western Churchill Province. Geological Society of America Abstracts with Programs, 44, 105.

Rutter, E.H. \& Brodie, K.H., 1992. Rheology of the lower crust. D.M. Fountain, R. Arculus, \& R. Kay (Eds.), The Geology of the Lower Continental Crust, Elsevier, Amsterdam, p. 201-267.

Schmid, S.M. \& Casey, M., 1986. Complete fabric analysis of some commonly observed quartz c-axis patterns. American Geophysical Union, Geophysical Monograph, 36, 263-286.

Schulte-Pelkum, V., Monsalve, G., Sheehan, A., Pandey, M.R., Sapkota, S., Bilham, R., \& Wu, F., 2005. Imaging the Indian subcontinent beneath the Himalaya. Nature, 435, 1222-1225.

Sherrington, H.F., Zandt, G., \& Frederiksen, A., 2004. Crustal fabric in the Tibetan Plateau based on waveform inversions for seismic anisotropy parameters. Journal of Geophysical Research, $109, \mathrm{~B} 02312$.

Slimmon, W.L., 1989. Bedrock compilation geology-Fon du Lac (NTS 74-O), Map 247A, scale 1:250,000, Saskatchewan Geological Survey, Saskatchewan Energy and Mines, Regina.

Snoeyenbos, D.R., Williams, M.L. \& Hanmer, S., 1995. Archean high-pressure metamorphism in the western Canadian Shield. European Journal of Mineralogy, 7, 1251-1272.

Trepied, L., Doukhan, J.C., Paquet, J., 1980. Subgrain boundaries in quartz: theoretical analysis and microscopic observations. Physics and Chemistry of Minerals, 5, 201-218.

Tullis, J., 2002. Deformation of granitic rocks: Experimental studies and natural examples. S. Karato \& H. Wenk (Eds.), Reviews in Mineralogy and Geochemistry (51): Plastic Deformation of Minerals and Rocks, The Mineralogical Society of America, Washington, DC, p. 51-95.

Vernon, R.H., 1979. Formation of late sillimanite by hydrogen metasomatism (base-leaching) in some high-grade gneisses. Lithos, 12, 143-152.

Warren, J.M., Hirth, G., \& Kelemen, P.B., 2008. Evolution of olivine lattice preferred orientation during simple shear in the mantle. Earth and Planetary Science Letters, 272, 501-512. 
Weiss, T., Siegesmund, S., Rabbel, W., Bohlen, T., \& Pohl, M., 1999. Seismic velocities and anisotropy of the lower continental crust: A review. Pure Applied Geophysics, 156, 97-122.

Wenk H.R. \& Tome, C.N., 1999. Modeling dynamic recrystallization of olivine aggregates deformed in simple shear. Journal of Geophysical Research, 104, 25513-25527.

White, S., 1977. Geological significance of recovery and recrystallization processes in quartz. Tectonophysics, 39, 143-170.

Williams, M.L. \& Jercinovic, M.J., 2002. Microprobe monazite geochronology: putting absolute time into microstructural analysis. Journal of Structural Geology, 24, 1013-1028.

Williams, M.L., Hanmer, S., Kopf, C. \& Darrach, M., 1995. Syntectonic generation and segregation of tonalitic melts from amphibolite dikes in the lower crust, Striding-Athabasca mylonite zone, Northern Saskatchewan. Journal of Geophysical Research, 100, 1571715734.

Williams, M.L., Jercinovic, M.J., Goncalves, P. \& Mahan, K.H., 2006. Format and philosophy for collecting, compiling, and reporting microprobe monazite ages. Chemical Geology, 225, $1-$ 15.

Williams, M.L., Melis, E.A., Kopf, C. \& Hanmer, S., 2000. Microstructural tectonometamorphic processes and the development of gneissic layering: a mechanism for metamorphic segregation. Journal of Metamorphic Geology, 18, 41-57.

Wintsch, R.P. \& Andrews, M.S., 1988. Deformation induced growth of sillimanite: "Stress" minerals revisited. Journal of Geology, 96, 143-161.

Yardley, B.W.D., 2009. The role of water in the evolution of the continental crust. Journal of the Geological Society of London, 166, 585-600.

Zhang, R.Y., Zhai, S.M., Fei, Y.W., \& Liou, J.G., 2003. Titanium solubility in coexisting garnet and clinopyroxene at very high pressure: the significance of exsolved rutile in garnet. Earth and Planetary Science Letters, 216, 591-601. 